\title{
In vitro epithelial-to-mesenchymal transformation in human adult epicardial cells is regulated by TGF $\beta$-signaling and WT1
}

\author{
Noortje A. M. Bax • Angelique A. M. van Oorschot • \\ Saskia Maas · Jerry Braun · John van Tuyn • Antoine A. F. de Vries • \\ Adriana C. Gittenberger-de Groot • Marie-José Goumans
}

Received: 15 October 2010/Revised: 25 March 2011/Accepted: 7 April 2011/Published online: 24 April 2011

(C) The Author(s) 2011. This article is published with open access at Springerlink.com

\begin{abstract}
Adult epicardial cells are required for endogenous cardiac repair. After myocardial injury, they are reactivated, undergo epithelial-to-mesenchymal transformation (EMT) and migrate into the injured myocardium where they generate various cell types, including coronary smooth muscle cells and cardiac interstitial fibroblasts, which contribute to cardiac repair. To understand what drives epicardial EMT, we used an in vitro model for human adult epicardial cells. These cells have an epithelium-like morphology and markedly express the cell surface marker vascular cell adhesion marker (VCAM-1). In culture, epicardial cells spontaneously undergo EMT after which the spindle-shaped cells now express endoglin. Both epicardial cells before and
\end{abstract}

Electronic supplementary material The online version of this article (doi:10.1007/s00395-011-0181-0) contains supplementary material, which is available to authorized users.

N. A. M. Bax · S. Maas - A. C. G. Groot

Department of Anatomy and Embryology,

Leiden University Medical Center,

Leiden, The Netherlands

A. A. M. van Oorschot - M.-J. Goumans ( $\square)$

Department of Molecular Cell Biology and Centre for

Biomedical Genetics, Leiden University Medical Center,

Einthovenweg 20, PO Box 9600,

2300 RC Leiden, The Netherlands

e-mail: M.J.Goumans@lumc.nl

J. Braun

Department of Cardiothoracic Surgery,

Leiden University Medical Center,

Leiden, The Netherlands

J. van Tuyn - A. A. F. de Vries

Virus and Stem Cell Biology Laboratory,

Department of Molecular Cell Biology, Leiden University

Medical Center, Leiden, The Netherlands after EMT express the epicardial marker, Wilms tumor 1 (WT1). Adding transforming growth factor beta (TGF $\beta$ ) induces loss of epithelial character and initiates the onset of mesenchymal differentiation in human adult epicardial cells. In this study, we show that TGF $\beta$-induced EMT is dependent on type-1 TGF $\beta$ receptor activity and can be inhibited by soluble VCAM-1. We also show that epicardial-specific knockdown of Wilms tumor-1 (WT1) induces the process of EMT in human adult epicardial cells, through transcriptional regulation of platelet-derived growth factor receptor alpha (Pdgfr $\alpha$ ), Snail and VCAM-1. These data provide new insights into the process of EMT in human adult epicardial cells, which might provide opportunities to develop new strategies for endogenous cell-based cardiac repair.

Keywords Epicardium - Human - Epithelialto-mesenchymal transformation - Transforming growth factor beta $(\mathrm{TGF} \beta) \cdot$ Wilms tumor 1 (WT1)

\section{Introduction}

The transformation of epithelial cells to a mesenchymal (EMT) phenotype is an important process for proper heart development. The development of the cardiac valves and septa of the heart is dependent on EMT of endocardial cells underlying the atrioventricular canal and endocardial cells underlying the outflow tract forming the endocardial cushions [16, 24, 36]. A distinct population of cells derived from the epicardium also undergoes EMT during cardiogenesis [30]. During embryogenesis, the epicardium originates from the proepicardial organ (PEO) recruited from the coelomic wall mesothelium at the venous pole of the heart. Cells derived from the PEO protrude to and cover the primitive heart tube. A part of these epicardial cells 
undergoes EMT, thereby forming epicardium-derived cells (EPDCs). As a result of EMT, EPDCs migrate into the subepicardium and subsequently into the myocardium [30, 51]. In the myocardium, EPDCs initially differentiate into interstitial fibroblasts [30] and later on into smooth muscle cells and adventitial fibroblasts of the coronary vasculature $[14,50]$. The contribution of EPDCs to heart development is not only structural, but also have a regulatory role in cardiogenesis. The mechanisms underlying this regulatory process are largely unknown, although it is likely that cellcell communication is of importance [30].

Previous in vitro studies have identified transforming growth factor beta (TGF $\beta$ ) as a key regulator of EMT in the embryonic PEO and embryonic epicardium in both mouse and chicken $[5,12,16]$. The TGF $\beta$-regulated EMT of chicken embryonic epicardial cells is dependent on the kinase activity of the TGF $\beta$ type I receptor or activin receptor-like kinase (ALK) 5 [5]. Furthermore, soluble vascular cell adhesion molecule-1 (VCAM-1) is able to inhibit TGF $\beta$-induced EMT [16]. Examination of the expression patterns of other growth factors present during embryonic development implies a role for fibroblast growth factor (FGF) and platelet-derived growth factor (PDGF) in epicardial EMT [6, 45]. Interestingly, the aforementioned roles of epicardial cells and EPDCs do not seem to be restricted to embryonic development. In the adult heart, the epicardium is a simple squamous epithelium, which functions as a smooth surface on which the heart slides in the pericardial cavity during contraction [30]. Over the last few years, several studies have focused on the role of adult epicardium and EPDCs in heart repair. Recently, we demonstrated that human adult spindle-shaped EPDCs, injected into the infarcted myocardium, preserved cardiac function and reduced remodeling both early and late after the onset of infarction [52]. These findings suggest that EPDCs could be a suitable cell source for cardiac cell therapy. Interestingly, recent in vivo studies showed that endogenous epicardium was reactivated after a myocardial infarction, thereby re-expressing embryonic markers such as raldh2, Tbx18 and WT1 [19, 29, 31, 44, 52]. Furthermore, reactivated epicardial cells proliferate and are able to undergo EMT, and after they migrate into the injured myocardium contribute to cardiac regeneration [19, 29, $31,44,52]$. These studies suggest that adult epicardium is a dynamic tissue, which is still able to generate EPDCs that can contribute to the adult ventricular wall. More insight into the signals that direct the process of EMT in adult epicardial cells would be beneficial for endogenously regulated cell-based cardiac repair, thereby providing the opportunity to investigate the possibilities to bypass the need for cell transplantation by stimulating repair by endogenous cells [33].
Therefore, the aim of this study was to gain more insight into the EMT process of human adult epicardial cells and to determine which factors are involved in EMT of human adult epicardium. We characterized human adult epicardial cells in vitro before and after EMT. Here, we describe that the cobblestone-like VCAM-1 expressing EPDCs (cEPDCs) upon TGF $\beta$ stimulation undergo specific morphological changes including the loss of epithelial characteristics. Spindle-shaped EPDCs (sEPDCs) have the appearance of a smooth muscle-like morphology and express endoglin, while VCAM-1 expression is inhibited in an ALK5-dependent manner. Furthermore, we show that WT1 is a repressor of the EMT process in human adult epicardial cells. Taken together with the expression patterns of TGF $\beta$ and WT1 after myocardial infarction, these new insights into the process of EMT in human adult epicardial cells may help in the development of therapies for cardiac repair.

\section{Materials and methods}

\section{Human specimens}

All experiments with human tissue specimens were carried out according to the official guidelines of the Leiden University Medical Center and with the approval of the institutional ethical committee.

\section{Harvesting and preparation of human epicardial cells}

Cultures of human epicardial cells with an epithelium-like morphology, also referred to as cobblestone-like EPDCs (cEPDCs), were prepared as described previously [49]. Briefly, EPDCs were cultured from the right atrial appendages excised during cardiac surgery from several adult patients. The layer of epicardium was stripped and minced into small pieces. The tissue pieces were cultured in a 1:1 mixture of Dulbecco's modified Eagle's medium (DMEM low glucose) and medium 199 (M199) containing $100 \mathrm{U} / \mathrm{ml}$ penicillin, $100 \mu \mathrm{g} / \mathrm{ml}$ streptomycin, $10 \%$ inactivated fetal calf serum (FCSi) (all from Invitrogen, Paisly, $\mathrm{UK}$ ), and $2 \mathrm{ng} / \mathrm{ml}$ basic fibroblast growth factor (bFGF) (Sigma-Aldrich, St. Louis, USA). The addition of bFGF stimulated outgrowth of cells from the tissue pieces and the proliferation of the cells. When the outgrowth of the epicardial cells was confluent, the cells were detached from the bottom of the culture dish with trypsin/EDTA (Invitrogen) solution. The cells were seeded in high density and cultured in a 1:1 mixture of DMEM and M199 supplemented with $100 \mathrm{U} / \mathrm{ml}$ penicillin, $100 \mu \mathrm{g} / \mathrm{ml}$ streptomycin and $10 \%$ FCSi to maintain the epithelium-like morphology (cobblestone-like EPDCs, cEPDCs). The medium was 
refreshed every 3 days. Stimulation experiments were performed with cEPDCs from passage (P) 2-4 of three different patients. In total, we used isolations from nine different right atrial appendages.

The purity of the human cEPDC cultures was certified with immunohistochemical staining for Wilms tumor-1 protein (WT1) (Calbiochem, San Diego, USA) at a dilution of 1:50.

For the in vitro stimulation experiments, cells were plated at a density of 20,000 cells $/ \mathrm{cm}^{2}$ and were allowed to attach for $24 \mathrm{~h}$ prior to the addition of growth factor or inhibitor.

\section{Addition of growth factors or inhibitors}

The medium was supplemented with the growth factors and inhibitors $24 \mathrm{~h}$ after seeding of the human adult cEPDCs. Growth factors TGF $\beta 3(1 \mathrm{ng} / \mathrm{ml})(\mathrm{R} \& D$ Systems Inc., Minneapolis, USA) and sVCAM-1 (100 ng/ml) (R\&D Systems) or small molecule inhibitors SB431542 (iALK5, $10 \mu \mathrm{M})$ (Sigma-Aldrich), $\alpha$-Endoglin antibody $(0.5 \mu \mathrm{g} / \mathrm{ml})$ (R\&D Systems) and Y27632 (iROCK $2.33 \mu \mathrm{g} / \mathrm{ml}$ ) (Calbiochem) were used. At $48 \mathrm{~h}$ after the addition of stimulators, cells were used for further analysis by immunohistochemical analysis, qPCR, Western blot analysis and an MTT assay.

\section{Immunophenotyping}

The surface antigen expression profiles of epicardial cells (cEPDCs) and epicardium-derived cells (sEPDCs) were determined by flow cytometry as described previously [49]. The antibodies used for flow cytometric analysis are listed in Table 1.

Immunohistochemical analysis

cEPDCs were cultured on glass chamber slides and, $48 \mathrm{~h}$ after stimulation, slides were subjected to immunohistochemical analysis [49]. Briefly, after fixation and permeabilization with $0.1 \%$ Triton, slides were incubated overnight with primary antibodies. The details of the antibodies are listed in Table 1. To investigate their morphology, the cells were immunofluorescently stained for $\beta$ catenin, phalloidin and $\alpha$-smooth muscle actin ( $\alpha$ SMA). Staining for $\beta$-catenin was performed overnight to detect cells with epithelial morphology, using an anti mouse FITC labeled secondary antibody. Prior to incubation $(1 \mathrm{~h})$ with phalloidin directly labeled with Rhodamine, cells were blocked with 3\% BSA/PBST for 45 min. For immunofluorescence, the nuclei were stained with 4',6-diamidino-2phenylindole (DAPI) (diluted 1:1,000 in PBS). Finally, the slides were mounted with Vectashield (Vector,
Table 1 Antibodies used for flow cytometry and immunohistochemistry

\begin{tabular}{|c|c|c|c|c|c|}
\hline Antigen & Source & Clone & Isotype & Label & Specie \\
\hline$\beta$-Catenin & $\mathrm{BD}$ & 14 & IgG1 & - & Mouse \\
\hline$\alpha / \beta$-Tubulin & CellSig & - & - & - & Rabbit \\
\hline$\alpha \mathrm{SMA}$ & SA & - & $\operatorname{IgG} 2 \mathrm{a}$ & - & Mouse \\
\hline CD31 & CLB & $\mathrm{HEC} / 75$ & $\operatorname{IgG} 1$ & FITC & Mouse \\
\hline CD34 & $\mathrm{BD}$ & $8 \mathrm{G} 12$ & IgG1 & $\mathrm{PE}$ & Mouse \\
\hline CD44 & $\mathrm{BD}$ & G44-26 C26 & $\operatorname{IgG} 2 b$ & $\mathrm{PE}$ & Mouse \\
\hline CD46 & $\mathrm{BD}$ & E4.3 & $\operatorname{IgG} 2 \mathrm{a}$ & FITC & Mouse \\
\hline CD90 & $\mathrm{BD}$ & $5 \mathrm{E} 10$ & $\operatorname{IgG1}$ & FITC & Mouse \\
\hline CD105 & Bio & SN6 & $\operatorname{IgG} 1$ & $\mathrm{PE}$ & Mouse \\
\hline CD106 & $\mathrm{BD}$ & 51-10C9 & $\operatorname{IgG} 1$ & $\mathrm{PE}$ & Mouse \\
\hline Endoglin & HM & - & - & - & Rabbit \\
\hline GAPDH & MP & $6 \mathrm{C} 5$ & $\operatorname{IgG} 1$ & & Mouse \\
\hline Id 1 & $\mathrm{SC}$ & & & & Rabbit \\
\hline Pai-1 & $\mathrm{SC}$ & & & & Rabbit \\
\hline pSmad1 & HM & - & - & - & Rabbit \\
\hline pSmad2 & HM & - & - & - & Rabbit \\
\hline VE-cadherin & $\mathrm{SC}$ & F8 & $\operatorname{IgG1}$ & - & Mouse \\
\hline Vimentin & SA & V9 & $\operatorname{IgG} 1$ & Су3 & Mouse \\
\hline WT1 & CA & - & - & - & Rabbit \\
\hline Goat IgG & MP & - & - & Alexa Fluor 568 & Rabbit \\
\hline Mouse Ig & Dako & - & - & FITC & Rabbit \\
\hline Mouse Ig & $\mathrm{BD}$ & - & - & FITC & Goat \\
\hline Mouse IgG1 & $\mathrm{BD}$ & X56 & $\operatorname{IgG} 1$ & $\mathrm{PE}$ & Rat \\
\hline Rabbit IgG & MP & - & - & Alexa Fluor 568 & Goat \\
\hline Mouse IgG2a & MP & - & $\operatorname{IgG} 2 \mathrm{a}$ & Alexa Fluor 488 & Goat \\
\hline Rabbit IgG & VL & - & - & Biotin & Goat \\
\hline Mouse IgG & VL & - & - & Biotin & Horse \\
\hline
\end{tabular}

All antibody preparations were used at the concentrations recommended by the suppliers. For an explanation of the abbreviations of the antigens, see the main text of the paper

$B D$ BD Biosciences, Bio Biocarta, $C A$ Calbiochem, $C L B$ Sanquin, CellSig Cell Signaling, Dako Dako Cytomation, $H M$ homemade, $M P$ Molecular Probes, SA Sigma-Aldrich, SC Santa Cruz, VL Vector Labs, FITC fluorescein isothiocyanate, $P E$ phycoerythrin

Burlingame, USA). Examination of the slides was performed using a fluorescence microscope and light microscope equipped with a digital camera (Diagnostics, RT3 slider, Sterling Heights, MI, USA).

Cells that were labeled with the antibody against $\alpha$ smooth muscle actin ( $\alpha \mathrm{SMA})$ were incubated with $5 \%$ bovine serum albumin (BSA, fraction V) in PBS (30 min) prior to the primary antibody, to block non-specific binding, Subsequently, cells were incubated in modified NETgel (50 mM Tris, pH 7.4, $150 \mathrm{mM} \mathrm{NaCl}, 5 \mathrm{mM}$ EDTA, $0.25 \%$ gelatin and $0.05 \%$ nonidet $\mathrm{P} 40$ ) with $0.5 \%$ BSA and an appropriate secondary antibody (see Table 1), carried out for 2 and $1 \mathrm{~h}$ at room temperature, respectively. The slides were mounted with Mowiol and analyzed using a fluorescence microscope (Zeiss Inc, New York, USA). 


\section{Western blotting}

For total protein extraction of cEPDCs under the described culture conditions, cells were trypsinized and the cell pellet was lysated in a sample buffer (SB) containing $10 \%$ SDS, $20 \%$ glycerol, $0,1 \%$ bromophenol blue, $5 \% \beta$-mercaptoethanol and Tris- $\mathrm{HCl}, \mathrm{pH}$ 6.8. Homogenates were sizefractionated on $10 \%$ PAGE gels and transferred to Hybond PVDF membranes. After blocking non-specific binding sites, membranes were incubated overnight with the antipSmad1 (previously described by Goumans et al. [22]), pSmad2 (previously described by Goumans et al. [22]), inhibitor of differentiation 1 (Id1), plasminogen activator inhibitor-1 (Pai-1), endoglin (previously described by Lebrin et al. [27]) and $\alpha$ SMA antibodies (Table 1) followed by incubation with a horseradish peroxidase (HRP)-labeled secondary antibody (goat anti-rabbit or rabbit anti-goat) for $1 \mathrm{~h}$. A competitive Western blot for GAPDH and $\alpha / \beta$-tubulin was performed to correct differences in protein concentration. Chemiluminescence was induced by ECL Advanced Detection reagent and detected by exposure to Hyperfilm ECL.

\section{MTT assay}

The total number of living cells as a measure for proliferation and viability was determined using a 3-(4,5dimethylthiazol-2-yl)-2,5-diphenyl tetrazolium bromide (MTT; Sigma-Aldrich) assay $(n=3)$. Cells were seeded in quatro in 95-well plates with 20,000 cells $/ \mathrm{cm}^{2}$ and stimulated as described previously. In addition, the different cultures were incubated for $3 \mathrm{~h}$ with MTT $(50 \mu \mathrm{g} / \mathrm{well})$ in fresh culture medium. The medium was removed and crystallized formazan dye in the cells was solubilized by adding dimethylsulfoxide (DMSO). Absorbance was measured at $540 \mathrm{~nm}$ using $690 \mathrm{~nm}$ as reference. Quantification was carried out by comparison absorbance after $48 \mathrm{~h}$ of stimulation with absorbance before stimulation.

\section{RNA interference}

Endoglin was knocked down using shRNA pTER technology [46], targeting the following 19-nucleotide sequence: 5'-GAAAGAGCTTGTTGCGCA-3' [10]. Oligonucleotides were cloned into the pTER vector under the control of the H1-RNA promoter. H1-RNA promoter and targeting sequence were subsequently transferred to the pRRLCMV-GFP vector using PstI and XhoI sites (opposite orientation of CMV-GFP cassette). The plasmid was then used for lentivirus production. cEPDCs were transduced with lentivirus expressing shRNAs that specifically target human endoglin, as described above, and control GFP virus. After $6 \mathrm{~h}$ of culturing in the presence of $8 \mu \mathrm{g} / \mathrm{ml}$ polybrene, the medium was refreshed. The day after the cells were plated in six-well plates and 2 days after transduction, cells were stimulated with TGF $\beta 3(1 \mathrm{ng} / \mathrm{ml})$ comparable to the other stimulation experiments.

mRNA isolation and quantitative RT-PCR analysis

Total RNA from cEPDCs stimulated as described was isolated using TriPure (Roche, Almere, The Netherlands) following the manufacturer's protocol. cDNA was synthesized from $750 \mathrm{ng}$ RNA per sample, using iScript cDNA synthesis kit (Fermentas, Leon-Rot, Germany). cDNA samples were subjected to quantitative RT-PCR (qRT-PCR) by using SYBRgreen (Roche) and a primer concentration of $10 \mu \mathrm{M}$. Primers were designed with Primer3 and qPrimerDepot (htp://primerdepot.nci.nih.gov/). Primer sequences and annealing temperatures are available on request. qRT-PCR was performed for the following factors: $W T 1$ isoform A, WT1 isoform D, TGF $\beta 1,2$, and 3, ALK1, ALK5, VCAM-1, E-cadherin, endoglin and Snail. qRT-PCR reactions were run on a 7900HT Applied Biosystems. PCR conditions were: $10 \mathrm{~min}$. at $95^{\circ} \mathrm{C}$ followed by 40 cycles of $30 \mathrm{~s}$ at $95^{\circ} \mathrm{C}, 30 \mathrm{~s}$ annealing temperature $\left(60^{\circ} \mathrm{C}\right)$ and $30 \mathrm{~s}$ at $72^{\circ} \mathrm{C}$. All samples were corrected for input based on housekeeping gene $\beta$-actin, which was not influenced by the different culture conditions (data not shown) and normalized to unstimulated conditions.

\section{Statistics}

All data of the volume measurements are presented as average \pm SEM. The PCR data were quantified using the $2^{-\Delta \Delta \mathrm{Ct}}$ method, by comparing signal of the sh-RNA treated groups with that of the control group, both relative to an internal control, $\beta$-actin. Analysis of the qRT-PCR data was performed with T test. Significance was assumed when $P<0.05$ using SPSS 16.0 software program (SPSS Inc. Chicago, USA). Graphics of statistical analysis were composed by Graphpad software. For simplification of the interpretation of the data, in all graphs representing the expression of mRNA of epithelial and EMT markers the fold inductions of the control and TGF $\beta 3$-stimulation were displayed.

\section{Results}

Analysis of cell surface marker profile

We expanded human cEPDCs from several atrial appendages and certified the purity of the cultures by WT1 staining (Fig. 1a, b). In both cEPDCs (Fig. 1a) and sEPDCs (Fig. 1b), WT1 was predominantly localized in the nuclei. The surface 
antigen profile of cEPDCs and SEPDCs was analyzed by flow cytometry (Table 1). As previously reported [49], sEPDCs abundantly expressed the TGF $\beta$ co-receptor endoglin (CD105) at their plasma membrane (Fig. 1c, d). The surface of cEPDCs was not decorated with endoglin, but contained substantial amounts of VCAM-1 (CD106) (Fig. 1c-e). For the other surface markers that were tested, cEPDCs and sEPDCs yielded similar results, i.e., hyaluronate receptor (CD44), membrane cofactor protein of the complement system (MCP; CD46) and major T-cell antigen (Thy1; CD90) were present. Neither cEPDCs nor sEPDCs expressed the hematopoietic marker CD34 or endothelial markers such as platelet-endothelial cell adhesion molecule-1 (PECAM-1; CD31) and vascular endothelial (VE)-cadherin at their cell surface (Fig. 1c).

\section{TGF $\beta$-signaling in epicardial cells}

Among the many molecules that regulate the EMT process in many different organs, there is one common element among them involving the TGF $\beta$ superfamily. Therefore, we examined the expression of the TGF $\beta$ type I receptors, ALK1 and ALK5, and found both ALK1 and ALK5 expressed in cEPDCs (Online Resource 1 and Fig. 2a) confirming that human cEPDCs are able to respond to TGF $\beta$. The patterns and abbreviations used in the graphs are depicted in Box 1 in Appendix. Interestingly, the addition of TGF $\beta$ increased the expression of ALK5 mRNA by 1.6-fold $(P<0.05)$ (Fig. 2a), while the expression of $A L K 1$ decreased by $30 \%(P<0.05)$ (Online Resource 1$)$. Furthermore, qRT-PCR confirmed the presence of $T G F \beta 1$, $T G F \beta 2$ and $T G F \beta 3$ transcripts in the human adult cEPDCs (Online Resource 2).

To test whether the TGF $\beta$-signaling pathway is functional in epicardial cells, we analyzed the expression of two defined downstream targets using Western blot analysis, Id 1 and Pai-1 as downstream targets of pSmad1/5 and $\mathrm{pSmad} 2 / 3$, respectively. We were not able to detect any Id1 protein 2 days after TGF $\beta$ stimulation (data not shown), although Pai-1 was present in all samples (Fig. 2b). The expression of Pai-1 was increased after TGF $\beta$ stimulation and markedly reduced if the ALK5 kinase inhibitor was added to the medium (Fig. 2b).

TGF $\beta$ causes loss of epithelial character

To determine whether the TGF $\beta$-signaling pathway is involved in EMT of human adult epicardial cells, we examined the effect of TGF $\beta$ stimulation on the epithelial character of these cells (Fig. 3a, b). Incubating cEPDCs with $\mathrm{TGF} \beta$ for $48 \mathrm{~h}$ resulted in elongation of the cells (Fig. 3b), which is indicative for EMT. To further confirm EMT, we stained with the epithelial marker $\beta$-catenin to mark cell-cell junctions and phalloidin to visualize filamentous actin. In untreated cells, $\beta$-catenin was localized in cell junctions (adherens junctions) and actin filaments were associated with these junctions (cortical actin filaments) (Fig. 3a2,3). When stimulated with $\operatorname{TGF} \beta$, the cEPDCs showed decreased expression and cytoplasmic redistribution of $\beta$-catenin (Fig. 3b2), while the actin filaments were clearly visible across the cells (stress fibers) (Fig. 3b3). These changes were consistent with the cellular events known to occur during EMT in which dissolution of organized cell junctions and reorganization of actin into stress fibers is needed to allow actin-myosin based contraction. TGF $\beta$ stimulation also caused increased staining of $\alpha$ SMA (Fig. 3b4), which was confirmed by Western blot analysis (Fig. 2c). Although $\alpha$ SMA expression increased after TGF $\beta$ stimulation, the cells still expressed WT1, demonstrating their undifferentiated state. To further explore this apparent loss of epithelial character, we examined the mRNA expression of E-cadherin, VCAM-1 and Snail by qRT-PCR (Fig. 2e) and the expression of endoglin by Western blot (Fig. 2c). Quantitative analysis of the epithelial markers E-cadherin and VCAM-1 after incubation with TGF $\beta$ showed significant decrease in $V C A M-1$ expression by $97 \% \quad(P<0.05)$, while the expression of E-cadherin did not change significantly (Fig. 2e). The expression of Snail, best known for its induction of phenotypic changes, increased by 1.5 -fold (Fig. 2e). Western blot analysis revealed that the expression of endoglin was not altered by the addition of TGF $\beta$ (Fig. 2c). These data show that in EPDCs, TGF $\beta$ causes loss of epithelial characteristics and induces the onset of differentiation into a smooth muscle cell phenotype.

ALK5 is required and sufficient for loss of epithelial character

To determine whether the TGF $\beta$-induced morphological changes which we observed in human adult epicardial cells is ALK5 dependent, we incubated cEPDCs with TGF $\beta$ in the presence or absence of the ALK5 kinase inhibitor (iALK5), SB431542, and observed that cEPDCs stimulated in the presence of iALK5 preserve their epithelial appearance. qRT-PCR analysis confirmed this epithelial phenotype, as the expression of $E$-cadherin mRNA was increased by $107 \%(P<0.05)$ in the presence of iALK5, although the expression of VCAM-1 decreased by $70 \%(P<0.05)$ (Fig. 2e). Western blot analysis showed that the addition of iALK5 markedly reduced endoglin levels (Fig. 2c). Cells incubated simultaneously with TGF $\beta$ and iALK5 did not elongate (Fig. 3d), and $\beta$-catenin and phalloidin were persistent at the cell junctions (Fig. 3d2,3). The decrease in expression of VCAM-1 and the increase of Snail mRNA by TGF $\beta$ was completely neutralized when iALK5 was added 

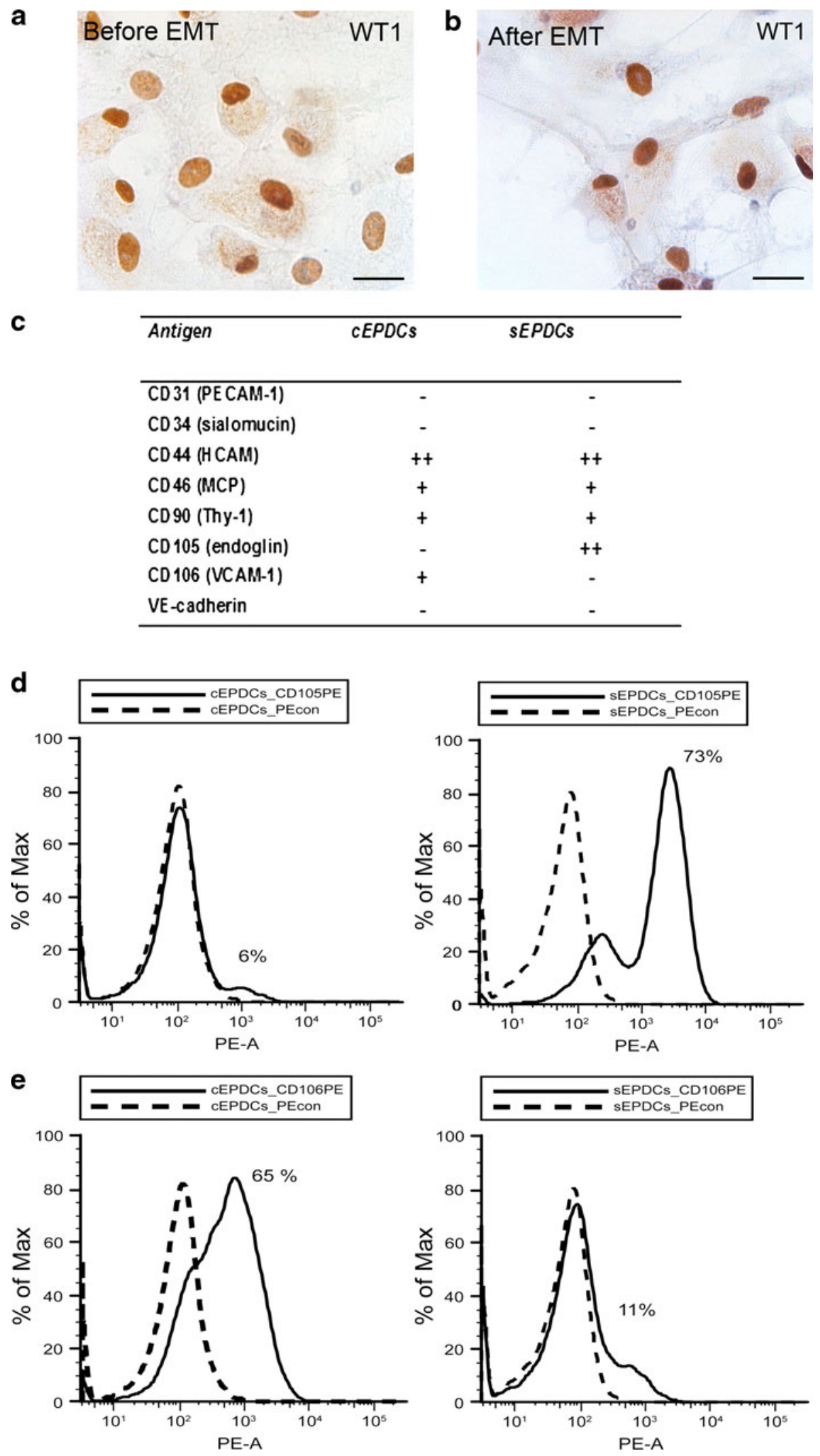

Fig. 1 Surface marker profile of human adult epicardial cells. EPDC cultures were stained using WT1 to certify the purity of the culture $(\mathbf{a}, \mathbf{b})$. Flow cytometric analysis of cultured adult human EPDCs before

(cEPDCs) and after EMT (sEPDCs) was performed (c). Histograms of endoglin (CD105) (d) and VCAM-1 (CD106) (e) are shown with isotype control (dashed line) and the specific signal (solid line). Scale bar $20 \mu \mathrm{m}$ 


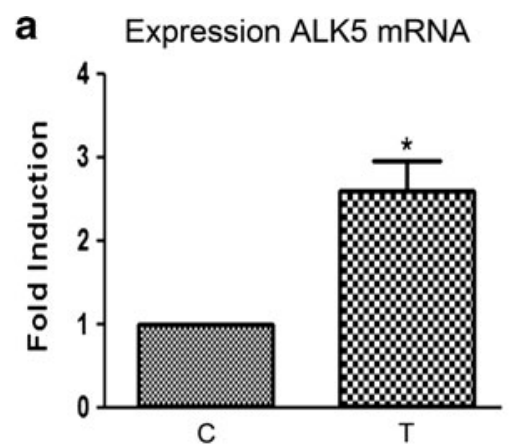

b Western blot analsyis
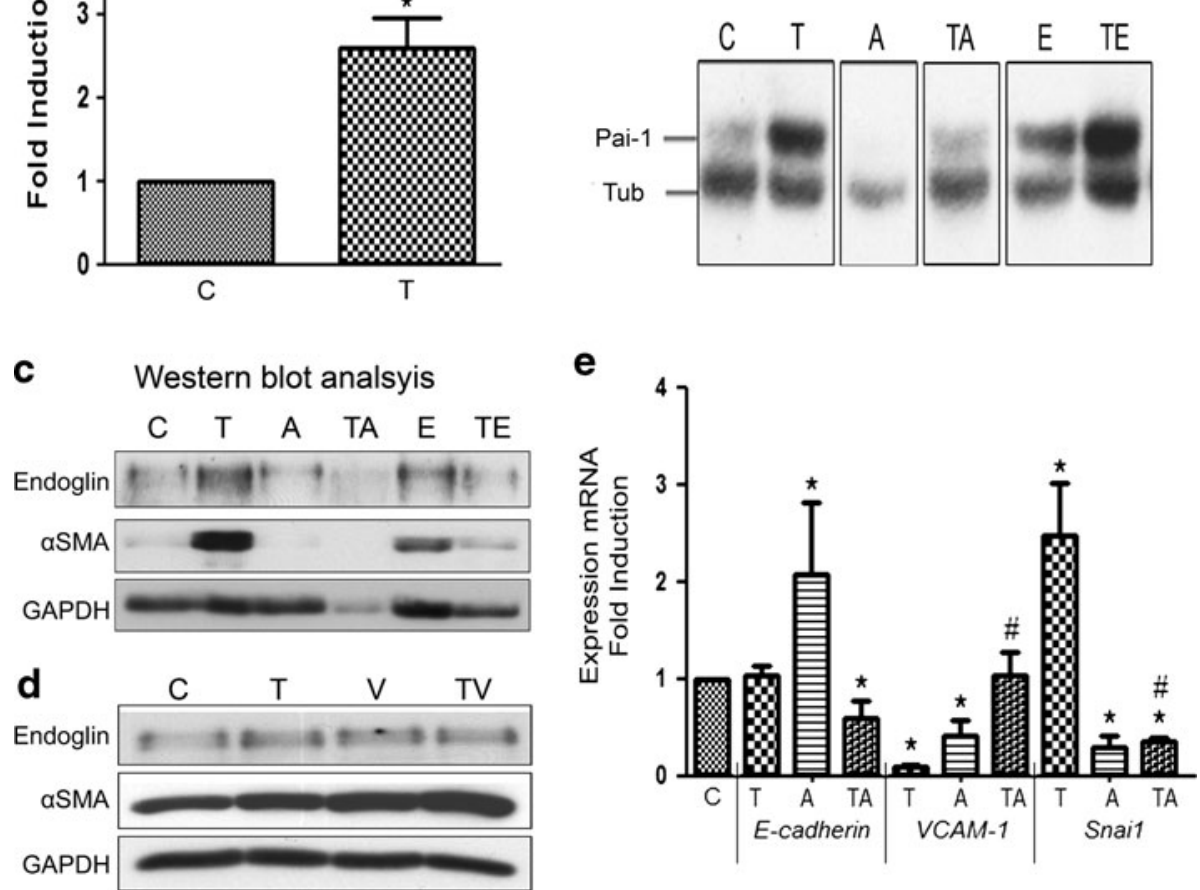

Fig. 2 Western blot and qRT-PCR analysis. Gene expression of cEPDCs (control; C) and cEPDCs treated with $1 \mathrm{ng} / \mathrm{ml}$ TGF $\beta 3$ (T) showed that the expression of $A L K 5$ was increased by TGF $\beta$ (a). Western blot analysis of protein samples isolated from cEPDCs stimulated in the presence or absence of $1 \mathrm{ng} / \mathrm{ml} \mathrm{TGF} \beta 3$ and $\alpha$-Endoglin probed for Pai-1 (b). As a loading control, $\alpha / \beta$-tubulin was used (b). Western blot analysis of $\alpha \mathrm{SMA}$ and endoglin in epicardial cells stimulated by sVCAM-1 (100 ng/ml) and $\alpha$-Endoglin

(Fig. 2e). Simultaneous addition of TGF $\beta$ and iALK5 markedly decreased the protein level of endoglin, comparable to the addition of iALK5 alone (Fig. 2c).

\section{RhoA in epicardial EMT}

$\operatorname{TGF} \beta$ is known to activate several downstream pathways independent of Smad-signaling, e.g., via RhoA-mediated activation [12]. To address the potential role of RhoA in $\operatorname{TGF} \beta$-stimulated loss of epithelial character in human adult epicardial cells, we inhibited the p160 rho kinase, a downstream effector of RhoA. cEPDCs were treated with Y27632, a specific inhibitor of p160-ROCK (rho-associated coiled-coil kinase) (iROCK) in the absence or presence of TGF $\beta 3$. The addition of iROCK caused elongation of the cells, which was accompanied with the decrease of $\beta$-catenin and phalloidin at the cell junctions (Online Resource 3). Stress fibers were not detected by phalloidin and also staining for $\alpha \mathrm{SMA}$ was below detection levels (Online Resource 3). Simultaneous addition of TGF $\beta$ and iROCK resulted in similar morphological changes as

$(0.5 \mu \mathrm{g} / \mathrm{ml})$ independent or simultaneously with TGF $\beta 3(1 \mathrm{ng} / \mathrm{ml})(\mathbf{c}$, d). GAPDH was used as a loading control in this experiment (c, d). Gene expression of cEPDCs and cEPDCs treated with TGF $\beta 3$, iALK5 and both simultaneously. Treatment with TGF $\beta$ showed significant decrease in epithelial markers and increase in EMT marker Snail, which is dependent on ALK5 kinase activity (e). $* P<0.05$ versus control, ${ }^{\#} P<0.05$ versus TGF $\beta 3$ stimulation. For patterns and abbreviations see Box 1 in Appendix

addition of iROCK alone, although stress fibers became visible across the cells (Online Resource 3). These data show that p160 rho kinase activity does not mediate the expression of smooth muscle cell markers in response to $\operatorname{TGF} \beta$.

VCAM-1 and endoglin alter the cytoskeleton of human adult EPDCs

Analysis of the cell surface marker profile showed spatiotemporal differences in VCAM-1 and endoglin expression. As the soluble form of the $\alpha 4 \beta 1$-integrin ligand VCAM (sVCAM) stimulates change in epicardial cells which restrict EMT and the fact that endoglin is part of the TGF $\beta$ receptor complex $[4,16]$, the question raised is whether VCAM-1 and endoglin are involved in the EMT process in human adult epicardial cells. To determine the cellular mechanism through which VCAM-1 inhibits epicardial EMT, we treated human adult cEPDCs with SVCAM-1 for $48 \mathrm{~h}$ and did not observe morphologic changes of the cells (Fig. 4b). The expression of $\beta$-catenin mRNA was 


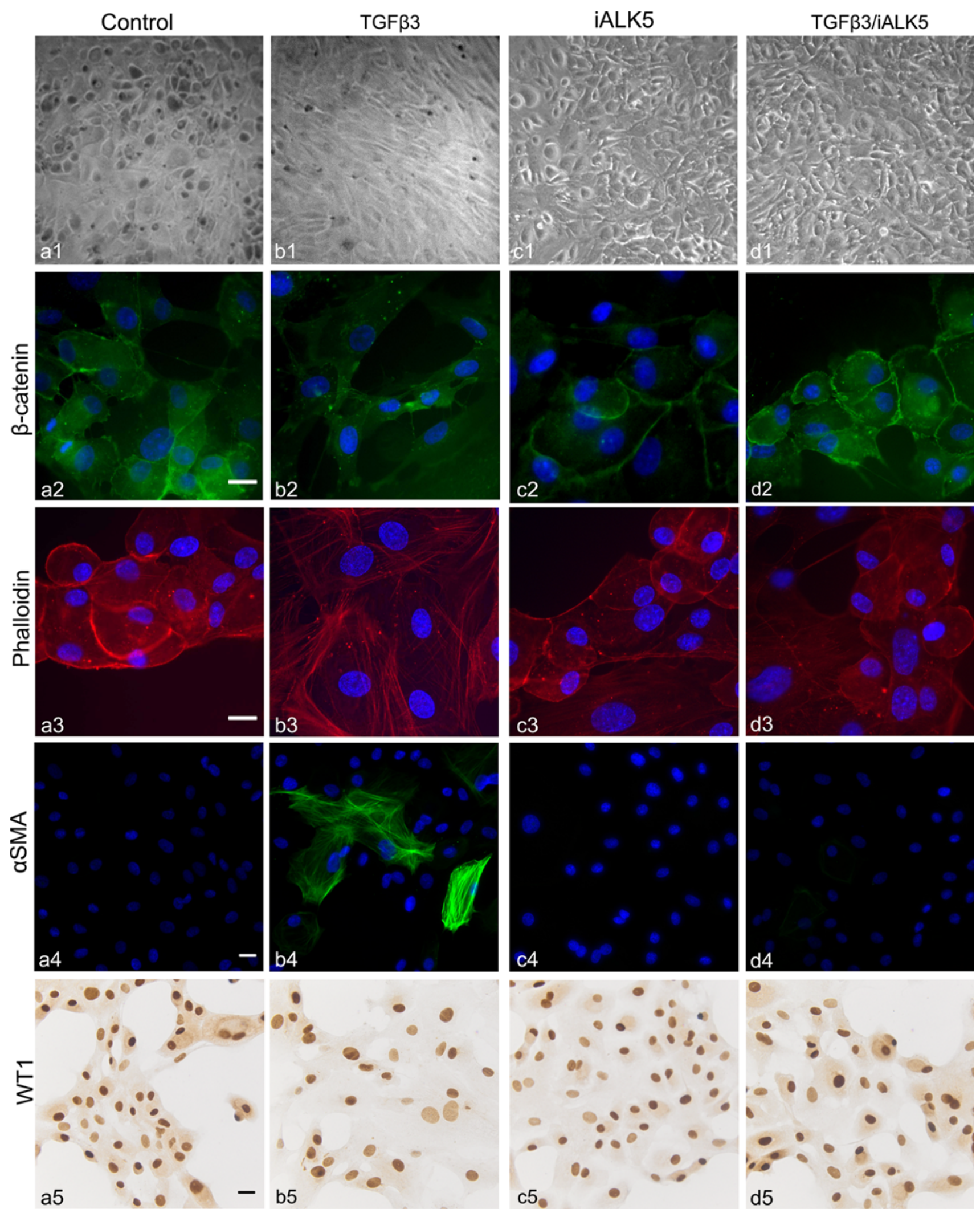

increased in cells stimulated with sVCAM-1 (Fig. 4b2), while there was a decrease in cortical actin filaments (Fig. 4b3). qRT-PCR for the epithelial markers E-cadherin and VCAM-1 and the EMT marker Snail showed that treatment with SVCAM-1 did not significantly change their mRNA expression (Fig. 4d). 
4 Fig. 3 TGF $\beta$-stimulated EMT is dependent on ALK5 kinase activity. Transforming growth factor (TGF $\beta$ ) induces epithelial-to-mesenchymal transformation (EMT) in human adult epicardial cells, and ALK5 is required for the effects of $\mathrm{TGF} \beta$. Epicardial cells were treated with $1 \mathrm{ng} / \mathrm{ml} \mathrm{TGF} \beta 3,10 \mu \mathrm{M}$ SB431542 (iALK5) and ALK5 kinase inhibitor for $48 \mathrm{~h}$ before fixation. Untreated epicardial cells display an epithelial phenotype (a) accompanied with expression of $\beta$-catenin (a2) and phalloidin (a3) at the cell-cell borders. Cells incubated with TGF $\beta$ are elongated, have lost $\beta$-catenin expression and phalloidin was visualized across the cells in stress fibers (b1-3). Cells treated with TGF $\beta$ express $\alpha$ SMA consistent with a smooth muscle phenotype (b4). In the presence of iALK5, cells display an epithelial phenotype (c) consistent with the untreated cells (a). Cells treated simultaneously with TGF $\beta$ and iALK5 retain expression of $\beta$-catenin at the cell border and no phalloidin staining across the cells is present (d). All untreated and treated cells express WT1 $($ a5-d5). $\times 100$ in a1-d1. Scale bar $20 \mu \mathrm{m}$

Since sVCAM-1 might stimulate the preservation of intercellular adhesion, we simultaneously treated cEPDCs with TGF $\beta$ and sVCAM-1. Remarkably, the presence of sVCAM-1 not only prevented the morphologic changes of the cells (Fig. 4c), but also prevented the formation of filamentous actin (Fig. 4c3) although there was alteration of $\beta$-catenin in cell junctions (Fig. 4c2). Strikingly, qRTPCR data showed that the expression of E-cadherin and Snail both increased significantly by 1.8 and 6.2 times, respectively, while the expression of VCAM-1 mRNA decreased significantly $(83 \%)$ in the presence of TGF $\beta$ and sVCAM-1 (Fig. 4d). These data show that sVCAM-1 is able to restrict TGF $\beta$-stimulated EMT.

Endoglin is a co-receptor modulating the TGF $\beta$ signal transduction pathway $[13,43]$ and is markedly present at the surface of the epicardial cells after EMT. Endoglin has been postulated to be involved in the cytoskeletal organization affecting cell morphology and migration [36]. To understand if and how endoglin functions in the EMT process, cEPDCs were incubated with an $\alpha$-Endoglin antibody (Fig. 5a). $\alpha$-Endoglin did not induce morphologic changes of cEPDCs. In cells treated with $\alpha$-Endoglin, the expression of $\beta$-catenin increased, which was accompanied with increased expression of E-cadherin and VCAM-1 by 74 and $64 \% \quad(P<0.05)$, respectively (Fig. 5b, c).
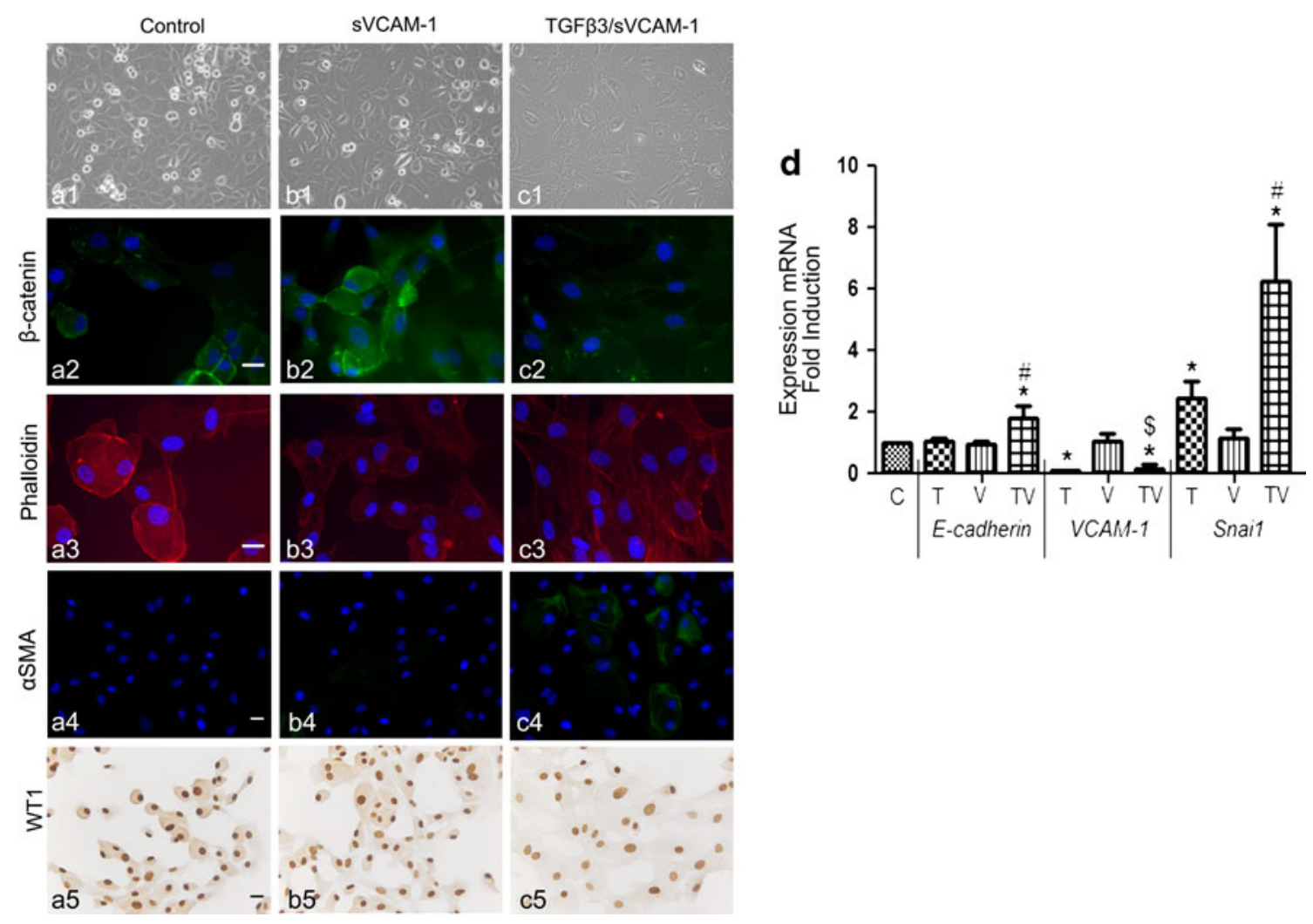

Fig. 4 sVCAM-1 inhibits cell shape changes in human adult epicardial cells treated with TGF $\beta 3$. Unstimulated cells (a) and stimulated with sVCAM-1 (100 ng/ml) (b) and simultaneously with TGF $\beta 3(1 \mathrm{ng} / \mathrm{ml})$ and sVCAM-1 $(100 \mathrm{ng} / \mathrm{ml})$ (c) are stained for $\beta$-catenin (a2-c2) and with phalloidin to visualize filamentous actin $(\mathbf{a 3}-\mathbf{c 3})$. Onset of differentiation into smooth muscle cells was visualized by staining for $\alpha$ SMA (a4-c4) and the state of

differentiation was visualized by WT1 (a5-c5). The process of EMT was confirmed by qRT-PCR (d) analysis for epithelial and EMT markers. $\times 100$ in a1-c1. Scale bar $20 \mu \mathrm{m} . * P<0.05$ versus control, ${ }^{\#} P<0.05$ versus TGF $\beta 3$ stimulation, ${ }^{\$} P<0.05$ stimuli versus simultaneous TGF $\beta 3 /$ stimuli. For patterns and abbreviations see Box 1 in Appendix 
Interestingly, Western blot analysis showed that addition of $\alpha$-Endoglin increased the protein levels of endoglin in human EPDCs (Fig. 2c). The $\alpha$-Endoglin antibody was not able to prevent the morphologic changes induced by TGF $\beta$, as evident by decreased $\beta$-catenin expression and an increased expression of phalloidin (Fig. 5b). qRT-PCR data showed a decrease in mRNA levels of VCAM-1 by $96 \%$ and increase of Snail by $118 \%$ (Fig. 5c). These data show that incubating human EPDCs with an endoglin antibody does not affect TGF $\beta$-induced EMT.

EMT in EPDCs is accompanied by a strong induction of endoglin. To ensure that the inability of the antibody to block TGF $\beta$-induced EMT is not caused by the high levels of endoglin, we analyzed the effect of endoglin knockdown on TGF $\beta$-induced EMT. Human adult cEPDCs were transduced with a lentivirus expressing an shRNA for human endoglin (shEndoglin) or eGFP as a control (Fig. 6a1, b1). Transduction of cEPDCs with shRNAs did not affect the epithelial morphology (Fig. 6a2, b2) and also the TGF $\beta$-induced morphological changes (Fig. 6a3, b3). EMT was confirmed by qRT-PCR showing a decrease in VCAM-1 (Fig. 6e) and increase of Snail mRNA (Fig. 6f). Although endogenous endoglin levels were reduced on both mRNA $(78 \%, P<0.05)$ and protein levels (Fig. 6c, d), the addition of TGF $\beta 3$ was able to induce endoglin at both the mRNA $(2.2$ times, $P<0.05)$ and protein levels in shEndoglin-transduced cells (Fig. 6c, d). These data show that knockdown of endoglin is not able to restrict TGF $\beta$ stimulated EMT and increase in endoglin expression.

\section{Role of WT1 in the process of EMT}

EMT is the onset for migration and/or differentiation of the epicardium. Therefore, we determined the differentiation state of the treated epicardial cells by analyzing the presence of WT1. WT1 is only expressed in epicardial cells if they are in an undifferentiated state. Immunohistochemistry shows that all treated epicardial cells express WT1 (Figs. 2, $3,4,5)$. To determine if the level of WT1 expression is affected by the treatment of the cells with several stimulators and inhibitors, we performed qRT-PCR analysis of WT1 mRNA expression. We observed decrease in WT1 expression in the presence of TGF $\beta$ by $68 \%(P<0.05)$ (Fig. 7a). Simultaneous addition of $\operatorname{TGF} \beta$ with either iALK5, sVCAM-1 or $\alpha$-Endoglin caused a decrease in WT1 expression by 45,35 and $78 \%$, respectively (Fig. 7a). Addition of iALK5, sVCAM-1 or $\alpha$-Endoglin alone did not change the expression of WT1 significantly (Fig. 7a).
Fig. 5 Inhibition of endoglin expression cannot block the process of TGF $\beta$-stimulated EMT. Blocking of endoglin increased the expression of epithelial markers $(\mathbf{a}, \mathbf{c})$. In simultaneous treatment of epicardial cells with TGF $\beta$ and $\alpha$-Endoglin, the decrease in epithelial and increase in mesenchymal and EMT markers stimulated by TGF $\beta$ could not be prevented $(\mathbf{a}-\mathbf{c}) .{ }^{*} P<0.05$ versus control, ${ }^{\$} P<0.05$ stimuli versus simultaneous TGF $\beta 3 /$ stimuli. $\times 100$ in a1-b1. Scale bar $20 \mu \mathrm{m}$. For patterns and abbreviations see Box 1 in Appendix
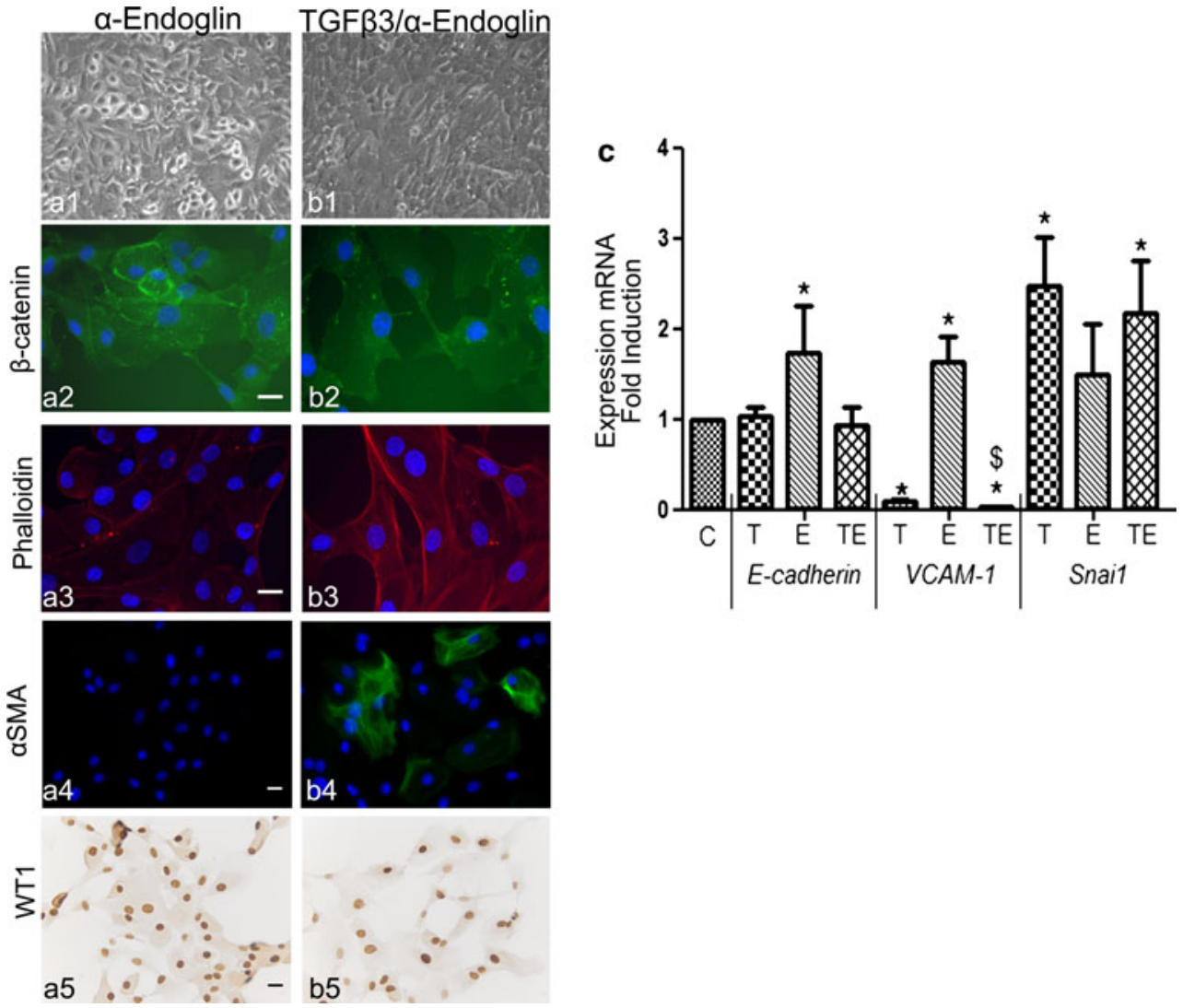

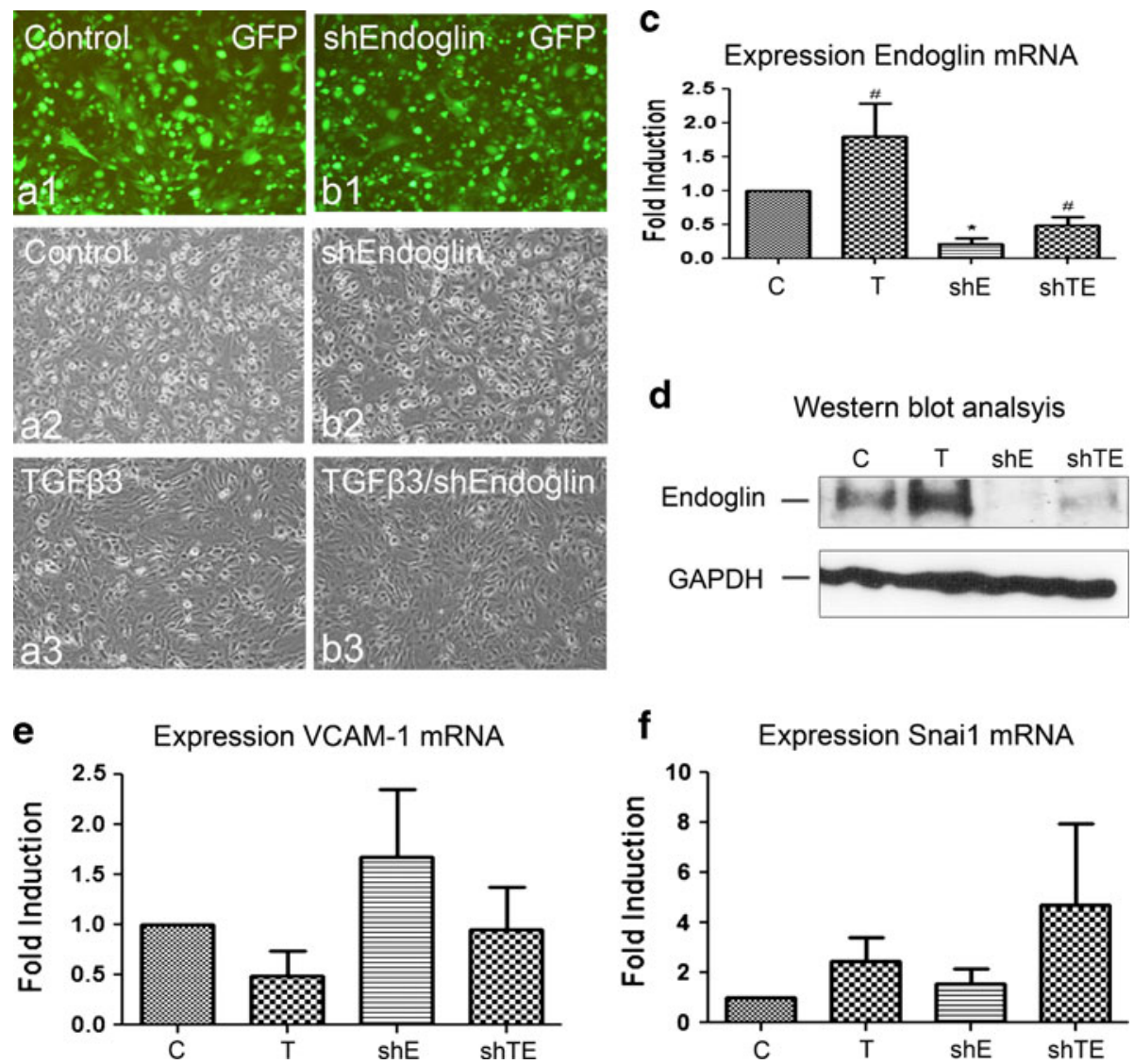

Fig. 6 Knockdown of endoglin expression cannot block the process of TGF $\beta$-stimulated EMT. Transduction of epicardial cells with lentivirus expression shRNAs for control GFP virus (Control) and human endoglin (shEndoglin) was visualized by the expression of GFP (a1, b1) and did not affect the cell morphology (a2, b2). Addition of TGF $\beta$ caused morphological changes in both shEndoglintransduced cEPDCs and control (a3, b3). qRT-PCR (c) and Western blot (d) analysis showed reduction of endogenous endoglin

As WT1 is high in the presence of factors preventing EMT and low in the presence of EMT stimulating factors, we explored the role of WT1 in the process of EMT. Therefore, we transduced human adult cEPDCs with shRNAs for WTl (shWT1). Morphological analysis showed elongation of the WT1 knockdown cells (Fig. 7d) when compared with the control and noncoding shRNA-transduced cells (Fig. 7b, c). qRT-PCR analysis for WT1 after transduction showed that $s h W T l$ transduction decreased the mRNA expression of the WTl isoform A and isoform D by 79\% $(P<0.05)$ (Fig. 7e) and 83\% $(P<0.05)$ (Online Resource 4), respectively. The observed elongation of the epicardial cells was accompanied with a decrease in the epithelial marker E-cadherin by $65 \%$ (Fig. 7f). The expression of $\alpha 4$-integrin and its ligand VCAM-1 (Fig. 7g, h) decreased by 14 and $35 \%(P<0.05)$, respectively, and the EMT marker Snail was increased by $98 \%$ after transduction of shWT1 $(P<0.05)$ (Fig. 7i). expression after transduction (c, d). Addition of TGF $\beta$ caused increase in endoglin expression in both transduced and control epicardial cells. Analysis of epithelial marker VCAM-1 (e) and EMT marker Snail (f) showed that knockdown of endoglin could not prevent the effects of TGF $\beta$ on these markers. $\times 100$ in a1-c2. ${ }^{*} P<0.05$ versus control, ${ }^{\#} P<0.05 \mathrm{TGF} \beta 3$ stimulation versus nonstimulated. $C$ control, $T$ TGF $\beta 3$; shE shEndoglin, shTE TGF $\beta 3 /$ shEndoglin

Role of platelet-derived growth factors in the process of EMT

The platelet-derived growth factor (PDGF)-signaling pathways were found to have a crucial role in EMT during cancer progression, since PDGF-A and its receptor PDGFR- $\alpha$ were highly elevated and secretion of PDGF-A was induced upon TGF $\beta$-induced EMT [20, 23]. We previously showed that there was a relation between WT1 and Pdgfr $\alpha$, which may affect the process of EMT [7]. Interestingly, mRNA expression of WT1 in human adult EPDCs is increased after shPdgfra transduction [7]. Furthermore, WT1 knockdown increased the expression of Pdgfro mRNA by $85 \%(P<0.05)$ (Fig. $7 \mathrm{j})$. To address the potential role of PDGFR- $\alpha$ and its ligand PDGF-A in TGF $\beta$-stimulated loss of epithelial character and the onset of smooth muscle differentiation in human epicardial cells, we analyzed the expression of Pdgfa (Fig. 8a) and Pdgfro 

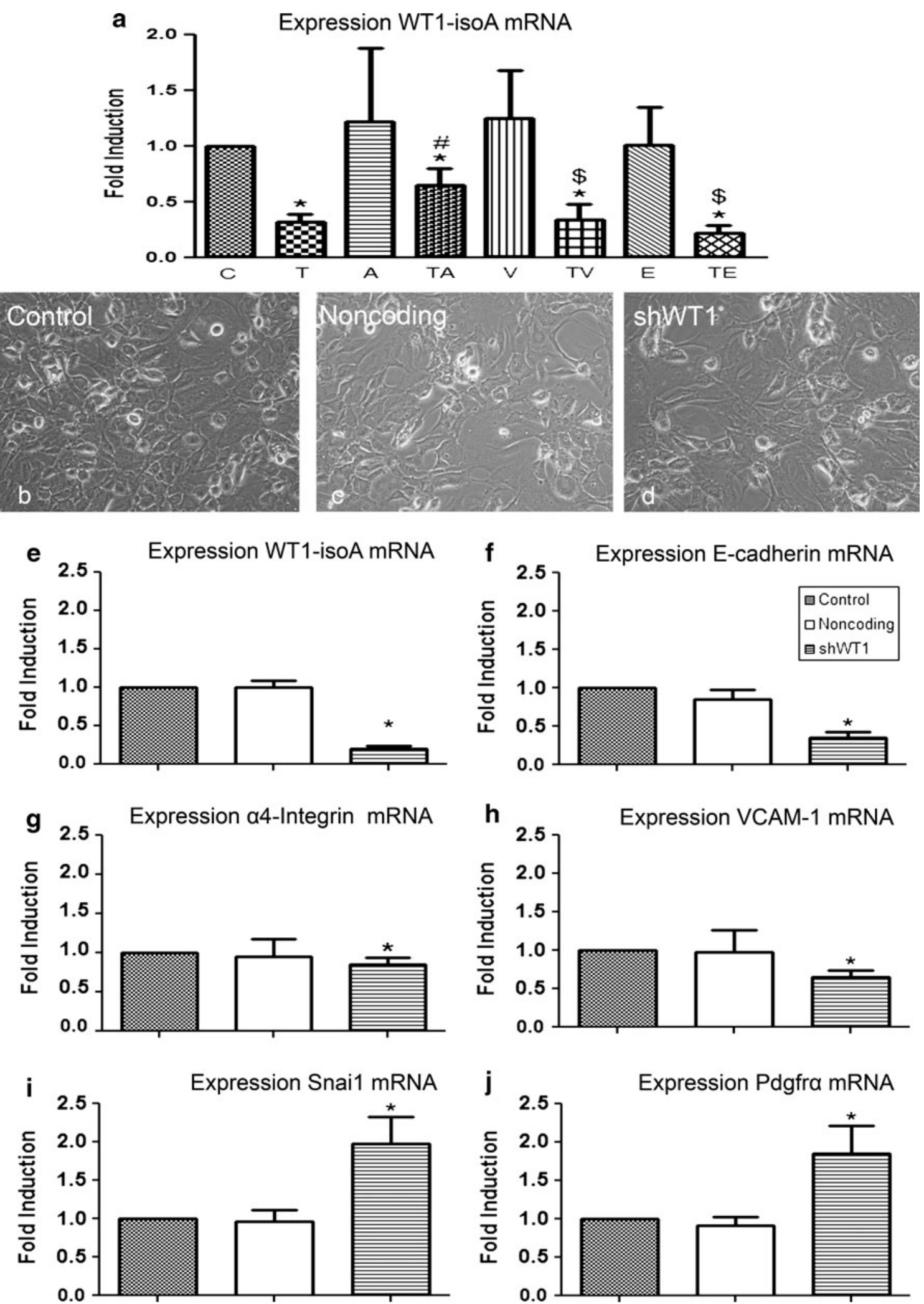

(Fig. 8b) mRNA after the addition of the different stimulators and inhibitors. In response to TGF $\beta 3$, the expression of $P d g f a$ increased by 1.5 -fold, while that of $P d g f r \alpha$ decreased by $70 \%(P<0.05)$ (Fig. 8$)$. iALK5 inhibited the effect of TGF $\beta$ on the expression of $P d g f a$ and $P d g f r \alpha$ (Fig. 8). The additions of sVCAM- 1 and $\alpha$-Endoglin were 
Fig. 7 Role of WT1 in the EMT process of human adult epicardial cells. Quantification of WT1 isoform A mRNA expression in human adult epicardial cells decreased after treatment with $\operatorname{TGF} \beta 3$ (a). Knockdown of $W T 1$ by shRNA results in loss of epithelial character of epicardial cells (b-d). Quantification of WT1 mRNA expression was significantly reduced in epicardial cells after knockdown of WT1 $(P<0.05)$ (e and Online Resource 3). The expression of epithelial markers E-cadherin (f), $\alpha 4$-integrin (g) and VCAM-1 (h) mRNA was decreased in epicardial cells after knockdown of WT1 $(P<0.05)$. The expression of EMT marker Snail increased significantly after knockdown of WT1 $(P<0.05)$ (i). WT1 knockdown caused a significant decrease in $P d g f r \alpha$ mRNA expression $(P<0.05)$ (j). ${ }^{*} P<0.05$ versus control, ${ }^{\#} P<0.05$ versus TGF $\beta 3$ stimulation, ${ }^{\$} P<0.05$ stimuli versus simultaneous TGF $\beta 3 /$ stimuli. For patterns and abbreviations see Box 1 in Appendix

not able to influence the effect TGF $\beta$ had on the expression of $P d g f \alpha$ and Pdgfr $\alpha$.

Regulation of proliferation/viability

Several studies showed that TGF $\beta$ modulates cell growth and viability. Using an MTT assay, the total number of living cells can be used as a measure for proliferation and
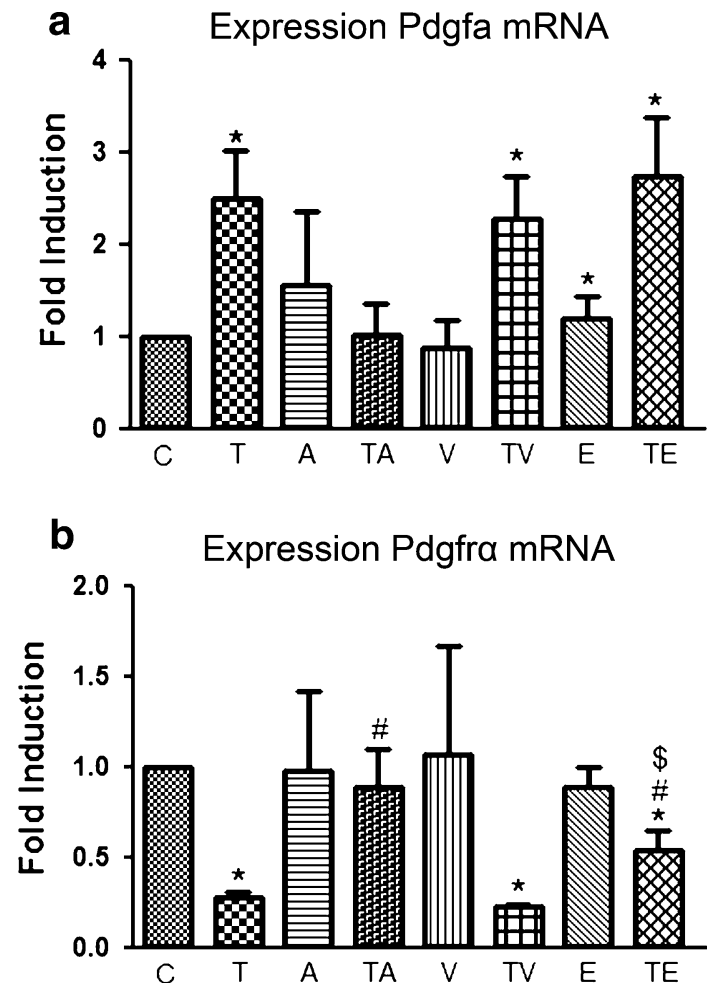

Fig. 8 PDGF-signaling in EMT. Quantification of $P d g f a$ (a) and $P d g f r \alpha$ (b) mRNA expression in human adult epicardial cells. The expression of $P d g f a$ increased (a) significantly $(P<0.05)$ after treatment with TGF $\beta 3$ in contrast to decrease of $P d g f r \alpha$ expression (b) $(P<0.05)$. Addition of sVCAM-1 or $\alpha$-Endoglin was not able to block the effect of TGF $\beta 3$ on Pdgfa (a) and Pdgfr $\alpha$ (b) mRNA expression $(P<0.05)$. ${ }^{*} P<0.05$ versus control, ${ }^{\#} P<0.05$ versus TGF $\beta 3$ stimulation, ${ }^{\$} P<0.05$ stimuli versus simultaneous TGF $\beta 3 /$ stimuli. For patterns and abbreviations see Box 1 in Appendix

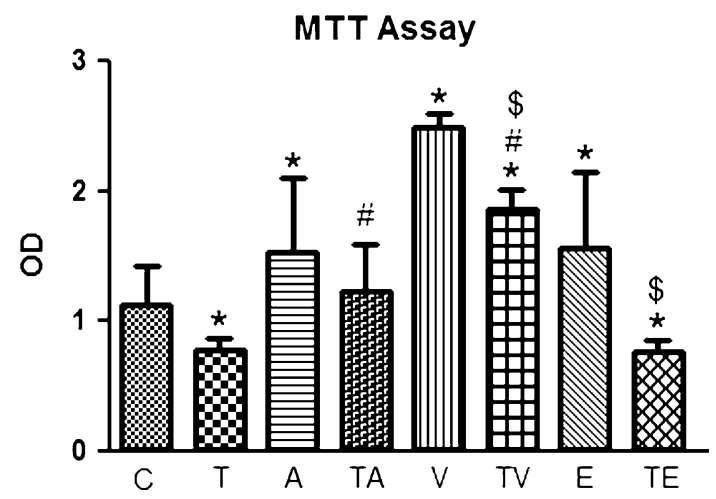

Fig. 9 Quantification of the number of epicardial cells by a MTT assay. TGF $\beta 3$ reduced the number of epicardial cells. Stimulation by inhibition of ALK5 (iALK5) and endoglin ( $\alpha$-Endoglin) induced the number of cells, as also did the addition of sVCAM-1. Simultaneous addition of TGF $\beta 3$ and iALK5 did not alter cell numbers compared to control and was able to block the effect of TGF $\beta 3$. Addition of sVCAM-1 was also able to block the effect of TGF $\beta 3$ and significantly increased the total cell number. Inhibition of $\alpha$-Endoglin was not able to block the effect of TGF $\beta 3$ and the number of epicardial cells reduced. ${ }^{*} P<0.05$ versus control, ${ }^{\#} P<0.05$ versus TGF $\beta 3$ stimulation, ${ }^{\$} P<0.05$ stimuli versus simultaneous TGF $\beta 3 /$ stimuli. For patterns and abbreviations see Box 1 in Appendix

viability. We observed that addition of TGF $\beta$ reduced the number of living epicardial cells by $31 \%$ compared to untreated cells $(P<0.05)$ (Fig. 9). The addition of iALK5 and sVCAM-1 increased the number of living epicardial cells by 37 and $130 \%(P<0.05)$, respectively (Fig. 9). Simultaneously, addition of TGF $\beta$ with iALK5 did not affect the number of epicardial cells compared to untreated cells, but there was a significant increase compared to cells treated with TGF $\beta$ alone (Fig. 9). Stimulation with sVCAM- 1 was able to prevent the negative effect of TGF $\beta$ on the number of living cells completely and the cell number increased by 58\% $(P<0.05)$ after simultaneous addition (Fig. 9). Inhibition of endoglin ( $\alpha$-Endoglin) significantly increased the number of living epicardial cells by $39 \%$ (Fig. 9). Blocking of endoglin was not able to inhibit the effect of $\operatorname{TGF} \beta$, as cells treated simultaneously with TGF $\beta$ and $\alpha$-Endoglin showed significant decrease in cell number by $38.4 \%(P<0.05)$ (Fig. 9).

\section{Discussion}

In this study, we show that human adult epicardial cells lose their epithelial character and gain $\alpha$ SMA expression when stimulated by TGF $\beta$. These effects are dependent on ALK5 kinase activity. TGF $\beta$-stimulated loss of epithelial character in adult epicardial cells seems to be independent of endoglin levels, but can be inhibited by induction of VCAM-1. Furthermore, we show that WT1 functions in the regulation of $P d g f r \alpha$ and both have a role in epicardial EMT. 
Our data demonstrate a role for the TGF $\beta / A L K 5$ signaling pathway in the regulation of EMT of human adult epicardial cells and in the onset of differentiation. The switch from VCAM-1 positive cEPDCs to endoglin expressing sEPDCs is accompanied with downregulation of VCAM-1, which triggers EMT. These new insights into the process of EMT in human adult epicardial cells may help to develop new therapies for cardiac repair, focused on modulation of VCAM-1 and WT1.

Adult EPDCs express VCAM-1 before, but endoglin after, EMT

Epicardial cells isolated from adult atrial appendages changed morphologically during EMT, which was accompanied by a reduction of $\beta$-catenin levels. More interestingly, while cEPDCs were characterized by expression of VCAM-1 on their cell surface and an absence of endoglin, sEPDCs did express endoglin and were negative for VCAM-1. Previous studies revealed that VCAM-1 restricts TGF $\beta$-stimulated EMT by inhibiting TGF $\beta$-mediated loss of $\beta$-catenin from intercellular junctions and enhances cell-cell adhesion [16]. Therefore, the expression of VCAM-1 and $\beta$-catenin are supportive for the epithelial nature of cEPDCs. Epicardial cells lose their epithelial characteristics under the influence of $\operatorname{TGF} \beta[5,12]$. Endoglin is an ancillary TGF $\beta$ co-receptor expressed on mesenchymal stem cells [40] and smooth muscle cells [10] and is involved in EMT [13, 43]. Together with the decreased expression of $\beta$-catenin at the plasma membrane of sEPDCs, endoglin expression in sEPDCs confirms EMT.

\section{Human adult epicardial EMT in vitro}

Our data demonstrate that TGF $\beta$-signaling induces loss of epithelial character of human adult cEPDCs and the onset of differentiation toward fibroblasts and/or smooth muscle cells, as previously reported for embryonic mouse and chicken epicardial cells $[5,12,16]$ and human mesothelial epicardial cells [15]. As TGF $\beta$ is expressed in the injured myocardium [11, 17, 42], reactivated epicardial cells probably undergo EMT and invade into the myocardium due to the local availability of active ligand. In all experimental conditions, human adult epicardial cells also express WT1, confirming their undifferentiated stage.

All human TGF $\beta$ isoforms (TGF $\beta 1-3$ ) signal by binding to a heterotetrameric complex of transmembrane serine/ threonine kinase receptors [21]. Upon ligand binding to the TGF $\beta$ type II receptor (TGF $\beta$ RII), the type I receptor (TGF $\beta$ RI or ALK5) is recruited into the complex and phosphorylated. The activated TGF $\beta$ RI kinase transduces the signal into the nucleus by phosphorylating Smad proteins required for EMT $[1,24]$. There is a third class of
TGF $\beta$ receptors, namely the co-receptors $\beta$-glycan and endoglin. Addition of TGF $\beta$ increased ALK5 expression and decreased the expression of another type I receptor ALK1. Also, the levels of Pai-1 were elevated, a known downstream target of the ALK5/Smad2/3-signaling cascade, and inhibition of the ALK5 kinase decreased Pai-1 expression, also confirming that EMT in human adult epicardial cells is regulated via the TGF/ALK5 pathway. Increased expression of ALK5 mRNA after TGF $\beta$ stimulation suggests a feed-forward loop.

The addition of TGF $\beta$ resulted in decreased number of human adult epicardial cells, suggesting less proliferation or cell viability. Previous studies using endothelial cells (ECs) showed that TGF $\beta$ inhibits the proliferation of ECs via the ALK5 pathway, while the ALK1-signaling cascade is responsible for the activation of proliferation [22, 27]. Although both type 1 receptors are expressed in epicardial cells, only the ALK5 pathway is necessary for TGF $\beta$ induced EMT.

VCAM-1 antagonizes TGF $\beta$-induced EMT in adult epicardial cells

Soluble VCAM-1 treatment inhibited TGF $\beta$-dependent loss of E-cadherin expression and preserved their epithelial character. Dokic et al. [16] reported that sVCAM-1 treatment leads to events that increase cortical actin association with the adherens junction and stabilizes adherens junction components at the membrane in embryonic chicken epicardial cells and rat epicardial mesothelial cells (EMCs). The presence of sVCAM-1 stabilizes the cell-cell contacts on the cell membrane, thereby preventing morphological changes. However, the TGF $\beta$-induced decrease in VCAM-1 mRNA expression and the increase of Snai 1 mRNA could not be blocked by sVCAM-1. One explanation could be that the change in gene expression and the loss of epithelial character are stimulated via different signaling pathways. In endothelial cells, TGF $\beta$ can transduce a signal using two pathways [22], the TGF $\beta /$ ALK5 pathway phosphorylating Smad2/3 and the TGF/ALK1 pathway activating Smad1. Interestingly, VCAM-1 is associated with Smad1, as Smad1 ${ }^{-1-}$ embryos lack the expression of VCAM-1 in the placenta [28]. Furthermore, human umbilical vein endothelial cells infected with constitutively active ALK1 increased the expression of VCAM-1, while constitutively active ALK5 reduced its expression [37]. These observations indicate that the ability of VCAM- 1 to alter TGF $\beta$ stimulated EMT probably depends on the stability of adherence junctions, while the TGF/ALK5 and TGF $\beta$ / ALK1 pathways are involved in regulating the expression of target genes, such as VCAM-1 and Snai1, and regulate the actual process of EMT. Future research needs to demonstrate if, like in endothelial cells, ALK1 is activated 
upon TGF $\beta$ stimulation in epicardial cells, and if sVCAM1 is able to activate TGF $\beta / A L K 1$ signaling. The upregulation of Snail seen in simultaneous stimulation of epicardial cells by TGF $\beta 3$ and sVCAM-1 is most likely regulated by the ALK5 pathway. Further studies of the signaling pathways altered by VCAM-1 and the modulation of VCAM-1 in human adult epicardial cells should allow us to elucidate the role of VCAM- 1 in TGF $\beta$-induced EMT.

The role of endoglin in EMT of adult epicardial cells

The presence of endoglin on the surface of epicardial cells that underwent EMT, suggested a role for endoglin in the process of EMT. This was supported by Mercado-Pimental et al. [36] who showed that loss of endoglin resulted in a direct perturbation of EMT during cardiac valve formation and reduced the expression of EMT markers including slug and Runx2. However, in our study, blocking of endoglin function by addition of $\alpha$-Endoglin antibody did not inhibit TGF $\beta$-induced EMT of the EPDCs. One explanation for the discrepancy compared to the study of Mecado-Pimental et al. [36] is the availability of endoglin for signaling. Using the antibody, we might not be able to occupy all receptors on the cell surface. shRNA knockdown of endoglin in human adult epicardial cells also did not restrict TGF $\beta$-induced morphologic changes in epicardial cells. These data suggest that endoglin is not directly involved in the initiation process of EMT in EPDCs as is shown for endothelial cells [27, 39], but might be beneficial for differentiation further on in the EMT-pathway.

\section{Wilms tumor suppressor WT1 and Pdgfr $\alpha$}

WT1 is a novel transcriptional activator of the $\alpha 4$-integrin gene and stimulation of $\alpha 4$-integrin expression by WT1 may promote cell adhesion in the epicardium [26]. Our data show that knockdown of WT1 in human epicardial cells stimulated the loss of epithelial morphology and reduced expression of E-cadherin, $\alpha 4$-integrin and VCAM1 significantly, while the expression of Snai1 increased significantly. This suggests that WT1 is a repressor of the EMT process in adult epicardial cells. These findings are consistent with previous described data of Bergmann and Kirschner [8, 26]. Bergmann et al. described that WT1 transcriptionally represses TGF $\beta$ [8], and Kirschner et al. described that WT1 transcriptionally activates $\alpha 4$-intergrin [26]. These data are similar to our observation, but opposite to the data described by Martinez-Estrada et al. [34]. Martinez-Estrada et al. generated immortalized tamoxifeninducible WT1-knockout epicardial cells (Cre+CoMEEC, E11.5). CoMEECs had typical cobblestone morphology and showed robust WT1 expression. Loss of WT1 after tamoxifen treatment led to a robust increase in E-cadherin expression and was associated with downregulation of N-cadherin, Snail and $\alpha$ SMA [34]. The contradiction between our data and Martinez-Estrada et al. could very well be caused by the fact that EMT in human adult epicardial cells is regulated by other factors compared to EMT in mouse embryonic epicardial cells. Further research is needed to elucidate the exact role of WT1 in the process of EMT in human adult epicardial cells.

Knockdown of WT1 and Pdgfra [7] suggested that there was a possible relation between these two factors. Previous study showed that both factors could inhibit the other factor in a significant manner, as shWT1 increased the Pdgfro expression and shPdgfra increased the expression of WTI in human adult epicardial cells [7]. PDGF-signaling is known to support epicardial EMT. Both PDGF receptors, $P d g f r \alpha$ and $P d g f r \beta$, are expressed in the epicardium [6, 35, 47]; PDGF-BB, which can bind to both $P d g f r \alpha$ and $P d g f r \beta$, is more potent in inducing cultured embryonic quail epicardial cells to undergo the initial steps of EMT [32] compared to both PDGF-AA and PDGF-AB, suggesting that this pathway is involved in epicardial EMT. A previous study showed an EMT-inducing role for Pdgfr $\alpha$ in mouse embryonic epicardial cells [7], as the receptor is able to repress WT1 expression. Unpublished data by Smith suggest that both receptors are required for the development of a unique epicardial derivative, $P d g f r \alpha$, for cardiac fibroblast and $P d g f r \beta$ for smooth muscle cells. This is in agreement with earlier observations that show that $P d g f r \alpha$ is more related to myocardial differentiation, while $\operatorname{Pdgfr} \beta$ is expressed during the stage of coronary artery formation [48]. Furthermore, PDGF-signaling stimulated the phosphorylation of Sox 9 and combined with TGF $\beta$ induces a transcriptional complex with Smad2 and Snai1 (Smith et al. personal communication). A previous study shows that WT1 is required for Sox9 expression [18] and that the expression of Sox9 is involved in the process of EMT during cardiac cushion development [2]. We show that during the process of EMT both WT1 and Pdgfr $\alpha$ are involved and more elaborate studies will be necessary to further explore the link between both growth factors and TGF $\beta$, Sox 9, Smad 2 and Snai1 and their potential roles in human adult epicardial EMT.

Interestingly, a role for PDGF-signaling in EMT is suggested in hepatocarcinogenesis, since PDGF-A ligand and PDGF receptor subunits were highly elevated upon TGF $\beta$-induced EMT [20]. Our data show that an increase of Pdgfa mRNA expression is accompanied by a decrease in Pdgfr $\alpha$ expression. This negative relation between PDGF-A and PDGFR- $\alpha$ has been previously described in chicken embryos in which epicardial outgrowth was inhibited [6]. Furthermore, Paulsson et al. [38] described that there was a density-dependent inhibitory effect of 
TGF $\beta$ on the expression of $P d g f r \alpha$. Therefore, our observed TGF $\beta$-regulated decrease of $P d g f r \alpha$ could also be due to an excess of TGF $\beta$-ligand. Future research on the role of $P d g f r \alpha$ mediated by TGF $\beta$ and/or WT1 in the EMT process is needed to be able to fully understand this intriguing cascade.

\section{Regenerative medicine}

Epicardial cells are a promising tool with regard to cardiac regeneration therapy. Transplantation of exogenous human adult EPDCs into the ischemic mouse myocardium improved left ventricular (LV) ejection fraction. Adverse remodeling was also attenuated by EPDCs injection [52]. The importance of epicardial cells and EPDCs for cardiogenesis and regenerative medicine is related to their role in coronary vessel development and maintenance of myocardial architecture [19, 29, 31, 44, 52]. Activation of endogenous epicardium stimulates the process of EMT, by which cells can migrate into the myocardium. Reactivation of the embryonic program of epicardial cells after myocardial injury is of great importance for the process of intrinsic cardiac repair. Understanding more of the process of EMT and the involved pathways in human adult epicardial cells is important for the development of strategies to stimulate heart repair by endogenous cell sources.

The members of the TGF $\beta$ superfamily are markedly induced in the infarcted myocardium and through their potent effects are capable of playing a central role in infarct healing and cardiac repair [11, 17, 42]. Our data combined with previous studies suggest that TGF $\beta$ is not only a central mediator involved in the inflammatory and fibrotic phase of healing and may critically modulate many cellular steps in post-infarction cardiac repair [11, 17, 42], but can also induce EMT of epicardial cells.

Thymosin beta 4 (T $\beta 4)$ is reported to activate endogenous mouse adult epicardium after myocardial infarction [41, 44]. This, combined with the knowledge from previous studies that $\mathrm{T} \beta 4$ significantly increase the expression of $\operatorname{TGF} \beta[9]$ and that T $\beta 4$ increases the secretion of Pai- 1 in endothelial cells [3], suggests that $\mathrm{T} \beta 4$ could be the initiator for the onset of the EMT-regulated pathway in adult epicardial cells (Fig. 10). Therefore, T $\beta 4$ might elevate $\operatorname{TGF} \beta$, thereby inducing EMT of epicardial cells and it would be very interesting to see if the effects of $\operatorname{TGF} \beta$ on VCAM-1, WT1 and Pdgfr $\alpha$ during EMT in human adult
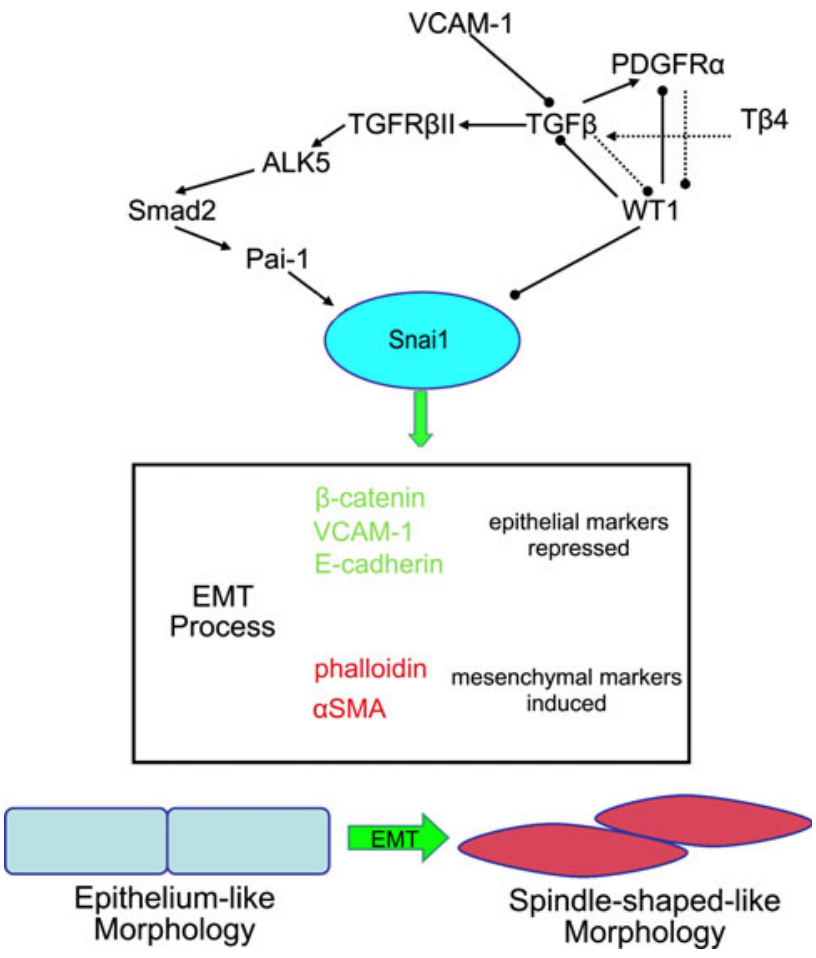

Fig. 10 Epithelial-to-mesenchymal transformation (EMT) of human adult epicardial cells. Master regulator of EMT, Snai1, leads to dramatic changes in gene expression profile and cellular morphology. Snail represses the expression of epithelial markers and triggers the expression of EMT markers. Herewith, we depict a possible pathway, which stimulates epicardial EMT after myocardial injury (adapted from Kang et al. [25]. Arrows with arrowheads represent activation and arrows with bullets represent repression. Dashed arrow lines with arrowheads and bullets represent indicative pathways

epicardial cells are initiated by $\mathrm{T} \beta 4$. Future research in cardiac repair, focusing on the potential of the TGF $\beta /$ ALK5 pathway initiating EMT of endogenous human adult epicardial cells investigation via transcriptional regulation of WT1 and Pdgfr $\alpha$, might provide new treatment modalities.

Acknowledgments We thank Zhe Zhao for his technical assistance with the Western blot and we thank Anke Smits for her assistance with the culture of EPDCs (both of the Department of Molecular and Cellular Biology, LUMC, Leiden, The Netherlands). We thank Duy Nguyen for his assistance with the immunofluorescent staining for $\alpha$ SMA (Department of Biomedical Engineering, Soft Tissue Biomechanics and Engineering, TU/e, Eindhoven, The Netherlands). This work was supported by a VIDI grant (016.056.319) from the Netherlands Organization for Scientific Research (NWO) to M.-J. Goumans. 
Open Access This article is distributed under the terms of the Creative Commons Attribution Noncommercial License which permits any noncommercial use, distribution, and reproduction in any medium, provided the original author(s) and source are credited.

\section{Appendix}

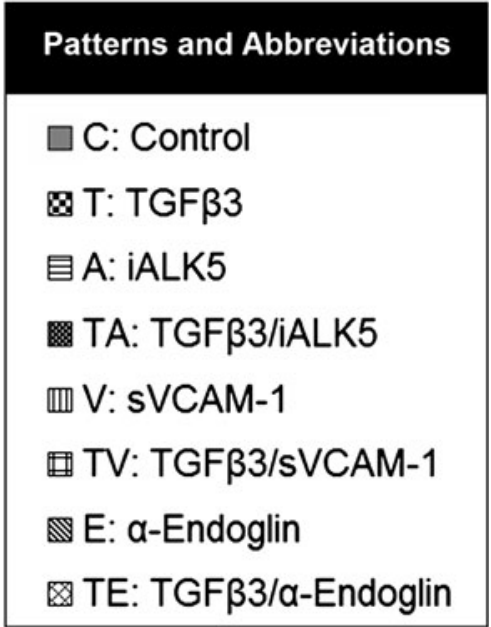

Box 1 Patterns and abbreviations

\section{References}

1. Abdel-Latif A, Zuba-Surma EK, Case J, Tiwari S, Hunt G, Ranjan S, Vincent RJ, Srour EF, Bolli R, Dawn B (2008) TGFbeta1 enhances cardiomyogenic differentiation of skeletal muscle-derived adult primitive cells. Basic Res Cardiol 103:514-524. doi:10.1007/s00395-008-0729-9

2. Akiyama H, Chaboissier MC, Behringer RR, Rowitch DH, Schedl A, Epstein JA, de Crombrugghe B (2004) Essential role of Sox 9 in the pathway that controls formation of cardiac valves and septa. Proc Natl Acad Sci USA 101:6502-6507. doi:10.1073/ pnas.0401711101

3. Al-Nedawi KN, Czyz M, Bednarek R, Szemraj J, Swiatkowska M, Cierniewska-Cieslak A, Wyczolkowska J, Cierniewski CS (2004) Thymosin beta 4 induces the synthesis of plasminogen activator inhibitor 1 in cultured endothelial cells and increases its extracellular expression. Blood 103:1319-1324. doi:10.1182/ blood-2003-04-1015

4. Arthur HM, Ure J, Smith AJ, Renforth G, Wilson DI, Torsney E, Charlton R, Parums DV, Jowett T, Marchuk DA, Burn J, Diamond AG (2000) Endoglin, an ancillary TGFbeta receptor, is required for extraembryonic angiogenesis and plays a key role in heart development. Dev Biol 217:42-53. doi:10.1006/dbio. 1999.9534

5. Austin AF, Compton LA, Love JD, Brown CB, Barnett JV (2008) Primary and immortalized mouse epicardial cells undergo differentiation in response to TGFbeta. Dev Dyn 237:366-376. doi: $10.1002 /$ dvdy. 21421
6. Bax NAM, Lie-Venema H, Vicente-Steijn R, Bleyl SB, Van Den Akker NMS, Maas S, Poelmann RE, Gittenberger-de Groot AC (2009) Platelet-derived growth factor is involved in the differentiation of second heart field-derived cardiac structures in chicken embryos. Dev Dyn 238:2658-2669. doi:10.1002/dvdy. 22073

7. Bax NAM, Bleyl SB, Gallini R, Wisse LJ, Hunter J, Van Oorschot AAM, Mahtab EAF, Lie-Venema H, Goumans MJ, Betsholtz C, Gittenberger-de-Groot AC (2010) Cardiac malformations in Pdgfrá mutant embryos are associated with increased expression of WT1 and Nkx2.5 in the second heart field. Dev Dyn 239:2307-2317. doi:10.1002/dvdy.22363

8. Bergmann L, Maurer U, Weidmann E (1997) Wilms tumor gene expression in acute myeloid leukemias. Leuk Lymphoma 25:435-443. http://informahealthcare.com/doi/pdf/10.3109/ 10428199709039030

9. Bock-Marquette I, Shrivastava S, Pipes GC, Thatcher JE, Blystone A, Shelton JM, Galindo CL, Melegh B, Srivastava D, Olson EN, DiMaio JM (2009) Thymosin beta4 mediated PKC activation is essential to initiate the embryonic coronary developmental program and epicardial progenitor cell activation in adult mice in vivo. J Mol Cell Cardiol 46:728-738. doi:10.1016/j.yjmcc.2009. 01.017

10. Bot PT, Hoefer IE, Sluijter JP, van Vliet VP, Smits AM, Lebrin F, Moll F, de Vries JP, Doevendans P, Piek JJ, Pasterkamp G, Goumans MJ (2009) Increased expression of the transforming growth factor-beta signaling pathway, endoglin, and early growth response-1 in stable plaques. Stroke 40:439-447. doi:10.1161/ STROKEAHA.108.522284

11. Bujak M, Frangogiannis NG (2007) The role of TGF-beta signaling in myocardial infarction and cardiac remodeling. Cardiovasc Res 74:184-195. doi:10.1016/j.cardiores.2006.10.002

12. Compton LA, Potash DA, Mundell NA, Barnett JV (2006) Transforming growth factor-beta induces loss of epithelial character and smooth muscle cell differentiation in epicardial cells. Dev Dyn 235:82-93. doi:10.1002/dvdy.20629

13. Dallas NA, Samuel S, Xia L, Fan F, Gray MJ, Lim SJ, Ellis LM (2008) Endoglin (CD105): a marker of tumor vasculature and potential target for therapy. Clin Cancer Res 14:1931-1937. doi: 10.1158/1078-0432.CCR-07-4478

14. Dettman RW, Denetclaw W, Ordahl CP, Bristow J (1998) Common epicardial origin of coronary vascular smooth muscle, perivascular fibroblasts, and intermyocardial fibroblasts in the avian heart. Dev Biol 193:169-181. doi:10.1006/dbio.1997.8801

15. Di Meglio F, Castaldo C, Nurzynska D, Romano V, Miraglia R, Bancone C, Langella G, Vosa C, Montagnani S (2010) Epithelial-mesenchymal transition of epicardial mesothelium is a source of cardiac CD117-positive stem cells in adult human heart. J Mol Cell Cardiol 49:7190727. doi:10.1016/j.yjmcc.2010.05.013

16. Dokic D, Dettman RW (2006) VCAM-1 inhibits TGFbeta stimulated epithelial-mesenchymal transformation by modulating Rho activity and stabilizing intercellular adhesion in epicardial mesothelial cells. Dev Biol 299:489-504. doi:10.1016/j.ydbio. 2006.08.054

17. Frantz S, Hu K, Adamek A, Wolf J, Salla A, Maier SKG, Lonning S, Ling H, Ertl G, Bauersachs J (2008) Transforming growth factor beta inhibition increases mortality and left ventricular dilatation after myocardial infarction. Basic Res Cardiol 103:485-492. doi:10.1007/s00395-008-0739-7

18. Gao F, Maiti S, Alam N, Zhang Z, Deng JM, Behringer RR, Lecureuil C, Guillou F, Huff V (2006) The Wilms tumor gene, $\mathrm{Wt} 1$, is required for Sox9 expression and maintenance of tubular architecture in the developing testis. Proc Natl Acad Sci USA 103:11987-11992. doi:10.1073/pnas.0600994103 
19. Gittenberger-de Groot AC, Winter EM, Poelmann RE (2010) Epicardium-derived cells (EPDCs) in development, cardiac disease and repair of ischemia. J Cell Mol Med 14:1056-1060. doi: 10.111/j.1582-4934.2010.01077.x

20. Gotzmann J, Fischer AN, Zojer M, Mikula M, Proell V, Huber H, Jechlinger M, Waerner T, Weith A, Beug H, Mikulits W (2006) A crucial function of PDGF in TGF-beta-mediated cancer progression of hepatocytes. Oncogene 25:3170-3185. doi:10.1038/sj.onc.1209083

21. Goumans MJ, Liu Z, ten Dijke P (2009) TGF-beta signaling in vascular biology and dysfunction. Cell Res 19:116-127. doi: $10.1038 / \mathrm{cr} .2008 .326$

22. Goumans MJ, Valdimarsdottir G, Itoh S, Rosendahl A, Sideras P, ten Dijke P (2002) Balancing the activation state of the endothelium via two distinct TGF $\beta$ type I receptors. EMBO J 21:1743-1753. doi:10.1093/emboj/21.7.1743

23. Jechlinger M, Sommer A, Moriggl R, Seither $P$, Kraut N, Capodiecci P, Donovan M, Cordon-Cardo C, Beug H, Grunert $S$ (2006) Autocrine PDGFR signaling promotes mammary cancer metastasis. J Clin Invest 116:1561-1570. doi:10.1172/ JCI24652

24. Joziasse IC, van de Smagt JJ, Smith K, Bakkers J, Sieswerda GJ, Mulder BJM, Doevedans PA (2008) Genes in congenital heart disease: atrioventricular valve formation. Basic Res Cardiol 103:216-227. doi:10.1007/s00395-008-713-4

25. Kang Y, Massague J (2004) Epithelial-mesenchymal transitions: twist in development and metastasis. Cell 118:277-279. doi: 10.1016/j.cell.2004.07.011

26. Kirschner KM, Wagner N, Wagner KD, Wellmann S, Scholz H (2006) The Wilms tumor suppressor Wt1 promotes cell adhesion through transcriptional activation of the alpha4integrin gene. J Biol Chem 281:31930-31939. doi:10.1074/jbc.M602668200

27. Lebrin F, Goumans MJ, Jonker L, Carvalho RL, Valdimarsdottir G, Thorikay M, Mummery C, Arthur HM, ten Dijke P (2004) Endoglin promotes endothelial cell proliferation and TGF-beta/ ALK1 signal transduction. EMBO J 23:4018-4028. doi:10.1038/ sj.emboj.7600386

28. Lechleider RJ, Ryan JL, Garrett L, Eng C, Deng C, WynshawBoris A, Roberts AB (2001) Targeted mutagenesis of Smad1 reveals an essential role in chorioallantoic fusion. Dev Biol 240:157-167. doi:10.1006/dbio.2001.0469

29. Lepilina A, Coon AN, Kikuchi K, Holdway JE, Roberts RW, Burns CG, Poss KD (2006) A dynamic epicardial injury response supports progenitor cell activity during zebrafish heart regeneration. Cell 127:607-619. doi:10.1016/j.cell.2006.08.052

30. Lie-Venema H, van den Akker NMS, Bax NAM, Winter EM, Maas S, Kekarainen T, Hoeben RC, DeRuiter MC, Poelmann RE, Gittenberger-de Groot AC (2007) Origin, fate, and function of epicardium-derived cells (EPDCs) in normal and abnormal cardiac development. ScientificWorldJournal 7:1777-1798. doi: 10.1100/tsw.2007.294

31. Limana F, Zacheo A, Mocini D, Mangoni A, Borsellino G, Diamantini A, De MR, Battistini L, Vigna E, Santini M, Loiaconi V, Pompilio G, Germani A, Capogrossi MC (2007) Identification of myocardial and vascular precursor cells in human and mouse epicardium. Circ Res 101:1255-1265. doi:10.1161/ CIRCRESAHA.107.150755

32. Lu J, Landerholm TE, Wei JS, Dong XR, Wu SP, Liu XS, Nagata K, Inagaki M, Majesky MW (2001) Coronary smooth muscle differentiation from proepicardial cells requires RhoA-mediated actin reorganization and p160 rho-kinase activity. Dev Biol 240:404-418. doi:10.1006/dbio.2001.0403

33. Madonna R, Rokosh G, De Caterina R, Bolli R (2010) Hepatocyte growth factor/Met gene transfer in cardiac stem cellspotential for cardiac repair. Basic Res Cardiol 105:443-452. doi: 10.1007/s00395-010-0102-7
34. Martinez-Estrada OM, Lettice LA, Essafi A, Guadix JA, Slight J, Velecela V, Hall E, Reichmann J, Devenney PS, Hohenstein P, Hosen N, Hill RE, Munoz-Chapuli R, Hastie ND (2010) Wt1 is required for cardiovascular progenitor cell formation through transcriptional control of Snail and E-cadherin. Nat Genet 42:89-93. doi:10.1038/ng.494

35. Mellgren AM, Smith CL, Olsen GS, Eskiocak B, Zhou B, Kazi MN, Ruiz FR, Pu WT, Tallquist MD (2008) Platelet-derived growth factor receptor beta signaling is required for efficient epicardial cell migration and development of two distinct coronary vascular smooth muscle cell populations. Circ Res 103:1393-1401. doi:10.1161/CIRCRESAHA.108.176768

36. Mercado-Pimentel ME, Runyan RB (2007) Multiple transforming growth factor $\beta$ isoforms and receptors function during epithelial-mesenchymal cell transformation in the embryonic heart. Cells Tissues Organs 185:146-156. doi:10.1159/000101315

37. Ota T, Fujii M, Sugizaki T, Ishii M, Miyazawa K, Aburatani H, Miyazono K (2002) Targets of transcriptional regulation by two distinct type I receptors for transforming growth factor-beta in human umbilical vein endothelial cells. J Cell Physiol 193:299-318. doi:10.1002/jcp. 10170

38. Paulsson Y, Karlsson C, Heldin CH, Westermark B (1993) Density-dependent inhibitory effect of transforming growth factor-beta 1 on human fibroblasts involves the down-regulation of platelet-derived growth factor alpha-receptors. J Cell Physiol 157:97-103. doi:10.1002/jcp.1041570113

39. Pece-Barbara N, Vera S, Kathirkamathamby K, Liebner S, Di Guglielmo GM, Dejana E, Wrana JL, Letarte M (2005) Endoglin null endothelial cells proliferate faster and are more responsive to transforming growth factor beta1 with higher affinity receptors and an activated Alk1 pathway. J Biol Chem 280:27800-27808. doi:10.1074/jbc.M503471200

40. Pittenger MF, Mackay AM, Beck SC, Jaiswal RK, Douglas R, Mosca JD, Moorman MA, Simonetti DW, Craig S, Marshak DR (1999) Multilineage potential of adult human mesenchymal stem cells. Science 284:143-147. doi:10.1126/science.284.5411.143

41. Riley PR, Smart N (2009) Thymosin beta4 induces epicardiumderived neovascularization in the adult heart. Biochem Soc Trans 37:1218-1220. doi:10.1042/BST0371218

42. Sakata Y, Chancey AL, Divakaran VG, Sekiguchi k, Sivasubramanian N, Mann DL (2008) Transforming growth factor-myocardial fibrosis in mice with cardiac-restricted overexpression of tumor necrosis factor. Basic Res Cardiol 103:60-68. doi: 10.1007/s00395-007-0689-5

43. Schmidt-Weber CB, Letarte M, Kunzmann S, Ruckert B, Bernabeu C, Blaser K (2005) TGF- $\{$ beta $\}$ signaling of human T cells is modulated by the ancillary TGF- $\{$ beta $\}$ receptor endoglin. Int Immunol 17:921-930. doi:10.1093/intimm/dxh272

44. Smart N, Risebro CA, Melville AA, Moses K, Schwartz RJ, Chien KR, Riley PR (2007) Thymosin beta4 induces adult epicardial progenitor mobilization and neovascularization. Nature 445:177-182. doi:10.1038/nature05383

45. Tomanek RJ, Lotun K, Clark EB, Suvarna PR, Hu N (1998) VEGF and bFGF stimulate myocardial vascularization in embryonic chick. Am J Physiol 274:H1620-H1626. http:// ajpheart.physiology.org/content/274/5/H1620.full.pdf + html

46. van de Wetering M, Oving I, Muncan V, Pon Fong MT, Brantjes H, van LD, Holstege FC, Brummelkamp TR, Agami R, Clevers H (2003) Specific inhibition of gene expression using a stably integrated, inducible small-interfering-RNA vector. EMBO Rep 4:609-615. doi:10.1038/sj.embor.embor865

47. Van Den Akker NM, Winkel LC, Nisancioglu MH, Maas S, Wisse LJ, Armulik A, Poelmann RE, Lie-Venema H, Betsholtz C, Gittenberger-de Groot AC (2008) PDGF-B signaling is important for murine cardiac development: Its role in developing 
atrioventricular valves, coronaries, and cardiac innervation. Dev Dyn 237:494-503. doi:10.1002/dvdy.21436

48. Van Den Akker NMS, Lie-Venema H, Maas S, Eralp I, DeRuiter MC, Poelmann RE, Gittenberger-de Groot AC (2005) Plateletderived growth factors in the developing avian heart and maturating coronary vasculature. Dev Dyn 233:1579-1588. doi: $10.1002 /$ dvdy. 20476

49. van Tuyn J, Atsma DE, Winter EM, van der Velde-van Dijke I, Pijnappels DA, Bax NAM, Knaan-Shanzer S, Gittenberger-de Groot AC, Poelmann RE, van der Laarse A, van der Wall EE, Schalij MJ, de Vries AA (2007) Epicardial cells of human adults can undergo an epithelial-to-mesenchymal transition and obtain characteristics of smooth muscle cells in vitro. Stem Cells 25:271-278. doi:10.1634/stemcells.2006-0366

50. Vrancken Peeters M-PFM, Gittenberger-de Groot AC, Mentink MMT, Poelmann RE (1999) Smooth muscle cells and fibroblasts of the coronary arteries derive from epithelial-mesenchymal transformation of the epicardium. Anat Embryol 199:367-378. doi: $10.1007 / \mathrm{s} 004290050235$

51. Wills AA, Holdway JE, Major RJ, Poss KD (2008) Regulated addition of new myocardial and epicardial cells fosters homeostatic cardiac growth and maintenance in adult zebrafish. Development 135:183-192. doi:10.1242/dev.010363

52. Winter EM, Grauss RW, Hogers B, van Tuyn J, van der Geest R, Lie-Venema H, Vicente-Steijn R, Maas S, DeRuiter MC, deVries AA, Steendijk P, Doevendans PA, van der Laarse A, Poelmann RE, Schalij MJ, Atsma DE, Gittenberger-de Groot AC (2007) Preservation of left ventricular function and attenuation of remodeling after transplantation of human epicardium-derived cells into the infarcted mouse heart. Circulation 116:917-927. doi:10.1161/CIRCULATIONAHA.106.668178 